\title{
Assessing the Effects of Directive 2014/95/EU on Nonfinancial Information Reporting: Evidence from Italian and Spanish Listed Companies
}

\author{
Stefanía Carolina Posadas * and Lara Tarquinio (1D \\ Department of Economic Studies, University “G. d'Annunzio" of Chieti-Pescara, 65127 Pescara, Italy; \\ 1.tarquinio@unich.it \\ * Correspondence: stefania.posadas@unich.it
}

Citation: Posadas, Stefanía Carolina, and Lara Tarquinio. 2021. Assessing the Effects of Directive 2014/95/EU on Nonfinancial Information Reporting: Evidence from Italian and Spanish Listed Companies. Administrative Sciences 11: 89. https://doi.org/ 10.3390/admsci11030089

Received: 27 July 2021

Accepted: 24 August 2021

Published: 31 August 2021

Publisher's Note: MDPI stays neutral with regard to jurisdictional claims in published maps and institutional affiliations.

Copyright: (c) 2021 by the authors. Licensee MDPI, Basel, Switzerland. This article is an open access article distributed under the terms and conditions of the Creative Commons Attribution (CC BY) license (https:// creativecommons.org/licenses/by/ $4.0 /)$.

\begin{abstract}
This paper explored the effects of new regulation on the disclosure of NFI in two European countries, Italy and Spain. The method used to develop the analysis is mainly qualitative. Content analysis was performed to verify the sustainability indicators disclosed by Italian and Spanish companies, listed on the FTSE MIB and IBEX 35 Indexes, before and after the Directive's publication and implementation in national legislation. The level of NFI disclosure was scored using a disclosure index. The comparative analysis found a progressive reduction in disclosure levels for Italian companies compared with Spanish companies, for which an expansion of the disclosure was detected. Moreover, a reduced gap between the quantity of NFI reported in the two countries was found. This is one of the few studies to use a 3-year longitudinal analysis to investigate the EU Directive's impact at the cross-country level.
\end{abstract}

Keywords: nonfinancial information; Directive 2014/95/EU; disclosure index; Italy; Spain

\section{Introduction}

Over the last few years, the European Commission has undertaken several initiatives aimed at reducing the shortcomings of voluntary reporting on social and environmental issues, which often offers an unbalanced, little transparent, low-quality, incomparable, and even misleading picture of the company (Boiral 2013; Diouf and Boiral 2017; García-Sánchez and Araújo-Bernardo 2020). On several occasions, the EU has highlighted the need to enhance corporate transparency and performance and encouraged European companies to develop a more sustainable approach (EU Commission 2014). The most extensive development in mandatory general transparency was undertaken with the adoption of the Directive 2014/95/EU, amending Directive 2013/34/EU as regards the disclosure of nonfinancial and diversity information by large undertakings and groups. Specifically, the EU Directive mandates public interest entities (PIEs) to draw up a nonfinancial statement including information related to "environmental, social and employee matters, respect for human rights, anti-corruption and bribery matters" (EU Commission 2014, par. 1). Therefore, Directive 2014/95/EU has led to a new European scenario for corporate reporting where nonfinancial information (NFI) disclosure changes from voluntary to mandatory. Italy was one of the first states to transpose the Directive into its legal system by Legislative Decree 254/2016, which entered into force on 25 January 2017. Although Italy had already envisaged the mandatory drafting of social reports for certain types of companies, numerous studies have shown a low propensity to voluntarily disclose social and environmental information and limited experience in the field of sustainability reporting (Mio and Venturelli 2013; Venturelli et al. 2017; Doni et al. 2019). These premises highlight, on the one hand, the potential contribution of the EU directive to NFI disclosure in Italy (Venturelli et al. 2019) and, on the other hand, the great difficulty that Italian companies could face in implementing the new requirements (Doni et al. 2019). Spain, on the contrary, 
was one of the last Member States to implement the EU Directive. The national transposition started through Royal Decree-Law 18/2017 on 24 November 2017, almost one year after the deadline (Curtó-Pagès et al. 2021). In this early stage, the implementation process did not include additional requirements beyond the EU provisions (Sierra-Garcia et al. 2018; Andrades et al. 2019). One year later, an extension of the Royal Decree-Law 18/2017 was established, leading to the publication of Law 11/2018 on 28 December 2018. This law incorporated the EU Directive into Spanish legislation by raising the level of rigorousness and transparency of NFI to be disclosed (Montesinos and Brusca 2019).

The decision in this study to focus on Italy and Spain comes from the consideration that although the transposition of the Directive in these two countries took place at different times, both countries have demonstrated strong communication and professionalism over time and taken leading ranks in terms of the rate of sustainability reporting diffusion by maturity (KPMG 2011, 2020). Moreover, only limited research has studied the EU Directive's impact at the cross-country level, with little analysis of NFI published before and after the new law (Mion and Loza Adaui 2019; Artene et al. 2020; Nicolò et al. 2020, 2021). No study has yet focused on the comparison between Italy and Spain in the transposition of the Directive. Therefore, to date, this is the first study aimed to analyse the effects of the Directive on both countries over three years. Indeed, the primary purpose of this study is to investigate the differences in the levels of NFI disclosed by Italian and Spanish listed companies over three years, namely, the year before the publication of the Directive, the year before its adoption into national legislation and the first year of its entry into force. Indeed, it is necessary to analyse the period before and after the introduction of a new law to understand its real impact (Doni et al. 2019; Mion and Loza Adaui 2019). This study aims to answer the following three research questions: (1) How did the new regulation influence companies' disclosure levels in Italy and Spain? (2) What are the sustainability indicators that companies of both countries are currently using to meet the Directive's demands compared with those used previously for reporting? (3) Did the NFI Directive's implementation lead to substantial changes in the adoption of assurance practices and, where already applied, in their characteristics?

This study uses institutional theory (DiMaggio and Powell 1983; Meyer and Rowan 1977) to assess the early phases of the institutionalisation of the new mandatory reporting practices of Italian and Spanish listed companies. Through institutional theory, it is possible to explore how institutional pressures related to coercive, normative, and mimetic forces produce effects on practices, values, and beliefs that became institutionalised within companies.

To this aim, a qualitative content analysis was performed on sustainability reports, integrated reports, and NFI disclosure drawn up by companies before and/or after the adoption of the EU directive. We explored only reports drawn up according to GRI standards or guidelines, focusing our attention on the sustainability indicators disclosed and the assurance practices of the companies in the sample.

This study contributes to both the theoretical and empirical literature on mandatory NFI reporting and the use of sustainability performance indicators. First, using the institutional theory lens, we want to contribute to understanding Italian and Spanish companies' responses to the new regulation and, more generally, enrich cross-country literature on the adoption of the new law. Only a limited number of studies have investigated how the shift from voluntary to mandatory NFI disclosure has influenced corporate disclosure performance by focusing on the extent of GRI indicators reported by companies (Sierra-Garcia et al. 2018; Raucci et al. 2020; Tarquinio et al. 2020). In addition, this is one of the few studies to evaluate the effects produced by legal provisions on the assurance procedures of nonfinancial disclosure. Indeed, as highlighted above, both Italian and Spanish transposition laws require the external verification of nonfinancial statements. Furthermore, the literature has often emphasised the positive relationship between the assurance of nonfinancial reports and the information disclosure level (Venturelli et al. 2017; Tarquinio et al. 2018; Caputo et al. 2020). 
This study has practical implications for policymakers assessing the new law's effectiveness in promoting nonfinancial reporting during the first stage of its implementation. Therefore, our findings can support the formulation of strategies useful for improving the transparency and harmonisation of NFI disclosure practices, with benefits for investors and stakeholders. Moreover, the focus on using sustainability performance indicators might support standard setters in evaluating and rethinking the type and characteristics of the indicators under this new scenario for NFI reporting.

The remainder of this paper consists of sections presenting the regulatory background and theoretical framework, literature review, methodology and method, results, discussion and conclusion.

\section{Regulatory Background and Theoretical Framework}

The Spanish and Italian regulatory contexts differ significantly. In Spain, mandatory regulations on social and environmental disclosure were applied before the Directive was adopted, albeit with little success. In 1998, the Spanish government introduced a law requiring companies to disclose environmental information in corporate financial statements, but as Bebbington et al. (2012) showed, a considerable level of noncompliance was detected. A significant step was taken through the publication of the Sustainable Economy Law 2/2011 (SEL), intended to reach meaningful progress in the area of sustainability reporting. Indeed, this Spanish law has been cited, together with the 2008 Act amending the Danish Financial Statement Act, as a precedent for the EU Directive (Garcia-Torea et al. 2020). Specifically, the SEL mandated companies exceeding $1000 \mathrm{em}$ ployees to publish a sustainability report and submit it to the State Council on Corporate Social Responsibility (SCCSR) (Luque-Vílchez and Larrinaga 2016). However, again, regulation on sustainability reporting failed to produce a real impact on the disclosure practices of Spanish companies (Luque-Vílchez and Larrinaga 2016; Sierra-Garcia et al. 2018).

In Italy, mandatory reporting on social and environmental issues did not exist until 1997, when it was envisaged only for certain types of not-for-profit organisations. More generally, Italian companies showed a low propensity to voluntarily disclose social and environmental information, resulting in limited experience in sustainability reporting (Mio and Venturelli 2013; Venturelli et al. 2017; Doni et al. 2019). These premises highlight, on the one hand, the potential contribution of the EU directive to NFI disclosure in Italy (Venturelli et al. 2019) and, on the other hand, the great difficulty that Italian companies could face in the implementation of the new requirements (Doni et al. 2019).

The NFI Directive granted the Member States some discretion when transposing the law into national legislation. It established a minimum set of mandatory disclosure requirements, but in some respects, it also provided a list of options to choose from (Aureli et al. 2020; Pizzi et al. 2020). The aim was to ensure the law's implementation across the Member States by accounting for the national context and any existing NFI disclosure requirements (CSR Europe and GRI 2017). Specifically, the options given refer to the location of NFI, the use of reporting standards or guidelines, the external verification of information by an independent assurance provider, the possibility for companies to omit information seriously prejudicial to their commercial position (Safe Harbour Principle), and the application of non-compliance penalties (EU Commission 2014). Moreover, Member States could use discretion to set requirements that exceeded the Directive provisions while remaining within the EU objectives (Aureli et al. 2020). Several Member States adapted and expanded the definitions of "large undertakings" and "PIEs", thus increasing the scope of the Directive (CSR Europe and GRI 2017). The specific national requirements set by the Italian and Spanish laws are shown in Table 1. 
Table 1. Summary of requirements set by the Italian and Spanish transposition laws.

\begin{tabular}{|c|c|}
\hline & Italy \\
\hline Company scope & $\begin{array}{l}\text { - } \quad \text { PIEs } \\
\text { - } \quad \text { Over } 500 \text { employees } \\
\text { - } \quad \text { Net turnover over EUR } 40 \text { million } \\
\text { or } \\
\text { Balance sheet total over EUR } 20 \text { million }\end{array}$ \\
\hline Location of NFI & $\begin{array}{l}\text { - In the management report } \\
\text { or } \\
\text { - In a separate report, approved by the } \\
\text { administrative body and at the disposal } \\
\text { of the supervisory body and the auditor, } \\
\text { within the deadline for the financial } \\
\text { statements, published on the company } \\
\text { register and alongside the } \\
\text { management report }\end{array}$ \\
\hline
\end{tabular}

\section{Spain}

- Over 500 employees

- PIEs

or

For two consecutive years, at least two of the following items:

- $\quad$ Net turnover over EUR 40 million;

- Balance sheet total over EUR 20 million;

- $\quad$ Over 250 employees

or administrative body and at the disposal within the deadline for the financial register and alongside the management report
- In the management report

or

- In a separate report, subject to the same approval, filing and publication rules as the management report
Reporting framework

National, international or EU based reporting framework
National, international or EU based reporting framework.

Use of indicators that comply with the European Commission's guidance and with the Global Reporting Initiative Standards

Presence and content of nonfinancial statement Presence and content of nonfinancial statement must be verified by an independent assurance provider must be verified by an independent assurance provider

\begin{tabular}{cl}
\hline Safe Harbour Principle & Applied \\
\hline & For omission of relevant \\
& information, non-compliance, or \\
Non-compliance penalties & failure to submit within timeframe, \\
& EUR 20,000-150,000 in sanctions \\
& will be applied \\
\hline
\end{tabular}

Not applied

Not specified

Numerous studies have highlighted the role of legal provisions in the disclosure of NFI (Moseñe et al. 2013; García-Sánchez et al. 2016; Martínez-Ferrero and García-Sánchez 2017; Dagilienè and Nedzinskienè 2018; Tiron-Tudor et al. 2019; Aureli et al. 2020; Tarquinio et al. 2020). These studies have used institutional theory as a conceptual framework, showing how the institutional environment in which companies operate influences corporate disclosure practices (Shabana et al. 2017; Lombardi et al. 2021). According to institutional theory, companies are influenced by their socio-institutional environment, to which they conform to gain legitimacy and ensure survival. One of the main components of institutional theory is the concept of isomorphism. Coercive, mimetic, and normative isomorphic processes influence organisations to conform to the recognised socially constructed systems of values, beliefs, norms, and definitions (Meyer and Rowan 1977; DiMaggio and Powell 1983; Suchman 1995). Coercive pressures stem from the regulatory legal system and societal expectations; normative pressures are associated with the professional norms and values defining a specific field; mimetic pressures refer to the imitation of successful or leading companies as a response to uncertainty (DiMaggio and Powell 1983). In this study, the EU Directive is seen as a coercive factor that, by making NFI mandatory, could affect corporate reporting practices, even in companies disclosing NFI even before its introduction. Indeed, regulation is considered one of NFI reporting's most influential drivers (de la Cuesta and Valor 2013; Tiron-Tudor et al. 2019). However, companies' response to coercive pressures is not uniform, but it can vary according to different factors, such as the national context 
(Dumitru et al. 2017; Rahman et al. 2019; Aureli et al. 2020). Therefore, our study aims to explore differences in the disclosure of NFI both over time, verifying the effects of the new law, and between two different countries to examine the role of national legislation in the transposition of the Directive and the implementation of pre-existing regulations in this area.

\section{Literature Review}

The introduction of the European Directive has stimulated scientific research on the effects of mandatory reporting on the quality and quantity of NFI.

The idea that regulation alone could increase NFI levels was initially widely spread in the academic literature (Venturelli et al. 2017; Caputo et al. 2020). In this sense, governments' imposition of specific rules and reporting models could harmonise NFI disclosure by facilitating benchmarking, enhancing the credibility of NFI, and increasing its accuracy and comprehensiveness (Allini and Manes-Rossi 2007; Crawford and Williams 2010; Caputo et al. 2020). On the other hand, some authors argued that better disclosure practices could not be achieved only through mandatory requirements (Bebbington et al. 2012; Luque-Vílchez and Larrinaga 2016; Doni et al. 2019). Regulation reduces the flexibility that is useful for capturing business-specific nonfinancial aspects (Allini and Manes-Rossi 2007; Venturelli et al. 2017) and could lead companies to exhibit responsible behaviour merely aiming at compliance (Tarquinio et al. 2020). Stronger dedication and commitment could be guaranteed by voluntary reporting practices, which confer more legitimacy on companies (Venturelli et al. 2017; La Torre et al. 2018). However, consensus has not yet been reached regarding mandatory or voluntary NFI reporting (Mazzotta et al. 2020). Indeed, several drawbacks are associated with voluntary disclosure, such as lack of accuracy, neutrality, objectivity, and comparability (Habek and Wolniak 2016; Caputo et al. 2020).

Several studies have verified the impact of the EU Directive at the single-country and cross-country levels. We focused on the studies that have investigated companies' reporting practices before or after their adoption of the Directive, and on those that have compared NFI disclosed before and after the new law entered into force. Figure 1 shows the studies that examine the effects produced by the implementation of the Directive in Italy, Spain, and at the cross-country level, grouped according to the above research streams identified in the academic literature.

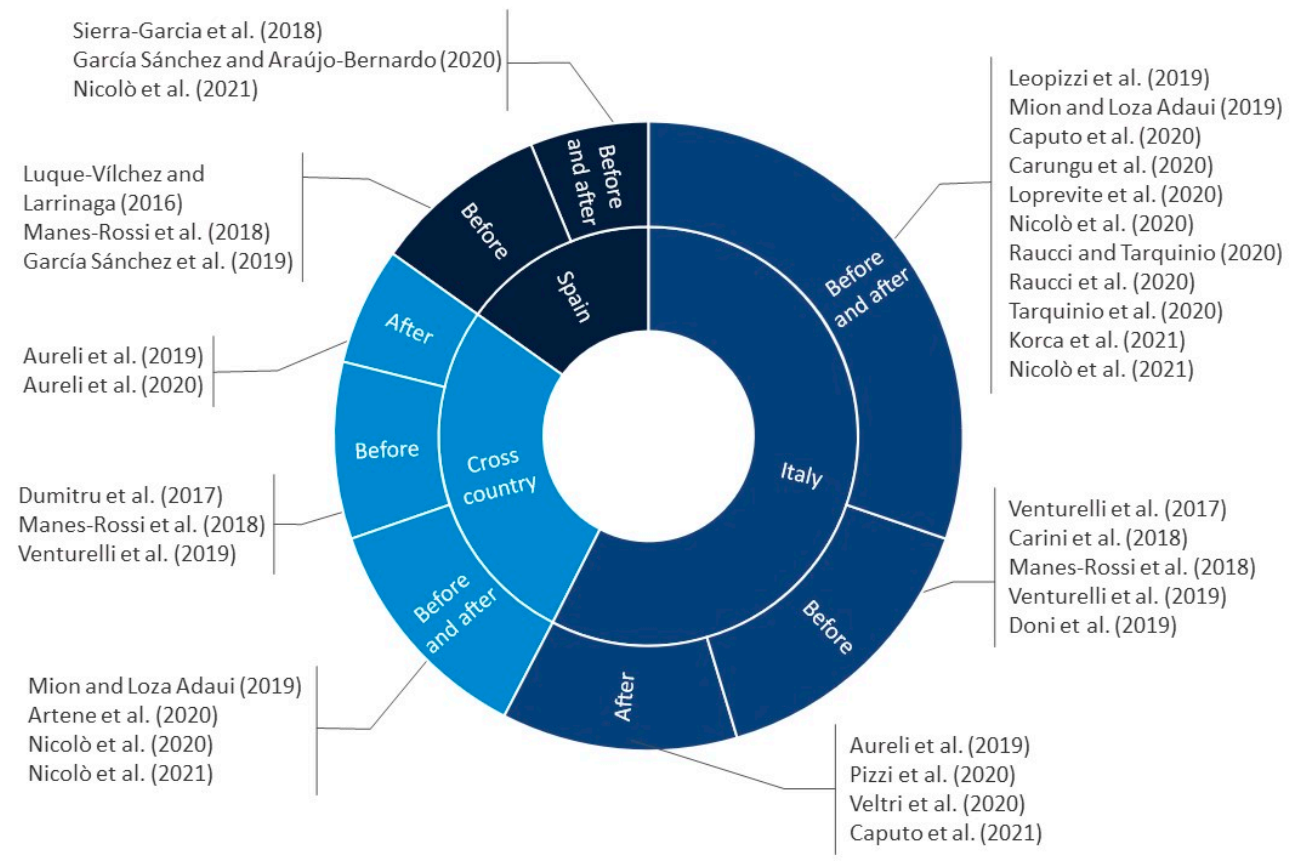

Figure 1. Overview of studies on the impact of the EU Directive in Italy, Spain, and at the crosscountry level. 
With reference to the Italian case, most of the studies compared NFI before and after the decree, showing, on the one hand, an increase in the quality of disclosure (Leopizzi et al. 2019; Mion and Loza Adaui 2019; Caputo et al. 2020; Nicolò et al. 2021) and, on the other hand, a general reduction in the number of sustainability indicators disclosed by Italian companies (Loprevite et al. 2020; Raucci and Tarquinio 2020; Raucci et al. 2020; Tarquinio et al. 2020). On the contrary, Korca et al. (2021) found a significant increase in the quantity but not in the quality of NFI. Other authors, instead, did not find a decisive influence of the Directive on disclosure levels (Carungu et al. 2020; Nicolò et al. 2020). Postimplementation analyses focused on subtopics of NFI, identifying a positive association between the quality of nonfinancial risk information and market value (Veltri et al. 2020), showing that corporate governance and report characteristics affect environmental information (Caputo et al. 2021), and revealing high heterogeneity in the quality of SDG reporting (Pizzi et al. 2021). Previous studies have analysed the information gap and the consequential adjustment required by the Directive based on the NFI disclosed before its implementation in national law (Venturelli et al. 2017; Carini et al. 2018; Manes-Rossi et al. 2018; Venturelli et al. 2019; Doni et al. 2019).

Studies on the impact generated by legislative changes in Spain are less numerous than studies related to the Italian case. Most of the Spanish studies aimed to explore the mandatory reporting of NFI by analysing the reporting behaviour of Spanish companies before the Directive's adoption (Luque-Vílchez and Larrinaga 2016; Manes-Rossi et al. 2018; García Sánchez et al. 2019). In addition, longitudinal analyses have been carried out to investigate changes in the impression management techniques used in nonfinancial reports (GarcíaSánchez and Araújo-Bernardo 2020) and in the location of NFI (Sierra-Garcia et al. 2018). Effects at the NFI level were only analysed with respect to reports drawn up after the publication of the Spanish adaptation, identifying a relationship between the level of regulatory compliance and the business sector (Sierra-Garcia et al. 2018).

From a comparative perspective, analyses were performed with different aims. Some studies analysed the convergence of national laws transposing the NFI Directive (Aureli et al. 2019; Aureli et al. 2020). Other studies have verified how the new legislation contributes to the harmonisation of NFI reporting practices and how it can affect the level of disclosure (Dumitru et al. 2017; Venturelli et al. 2019; Mion and Loza Adaui 2019; Artene et al. 2020). On an international level, Manes-Rossi et al. (2018) analysed the compliance level of the 50 largest European companies, while Nicolò et al. (2020) addressed the impact of the EU Directive on the NFI provided in the integrated reports of 22 European state-owned enterprises. Moreover, Nicolò et al. (2021) verified the effects of the EU legislation on the ESG information disclosed by 1392 European listed firms. Italy was included in six of these studies (Manes-Rossi et al. 2018; Venturelli et al. 2019; Aureli et al. 2019; Mion and Loza Adaui 2019; Nicolò et al. 2020, 2021), and Spain was included in two of them (Manes-Rossi et al. 2018; Nicolò et al. 2021). Significant differences in NFI quality were found between Italy and Germany (Mion and Loza Adaui 2019) and between Italy and the UK (Venturelli et al. 2019). Mion and Loza Adaui (2019) selected Italy and Germany to examine the effects of introducing mandatory requirements in two similar contexts where NFI reporting was voluntary before the adoption of the EU Directive. Venturelli et al. (2019) evaluated nonfinancial reporting before the application of the EU regulation in two countries with different legal systems. In fact, in the UK, the Companies Act 2006 mandated NFI to be published in strategic reports almost a decade before the Directive was introduced (Venturelli et al. 2019; Aureli et al. 2019). Our study follows this last approach.

As shown in Figure 1, limited studies have investigated the EU Directive's impact at the cross-country level, scarcely analysing the NFI published before and after the new law's introduction. To address this gap, our study examines the evolutionary path of NFI in the EU Directive scenario through an analysis of the pre- and post-implementation of the Directive by Italian and Spanish listed companies. 


\section{Methodology and Method}

To investigate how Directive 2014/95/UE has affected the NFI disclosed by Italian and Spanish listed companies, we performed a content analysis to verify the quantity and typology of Global Reporting Initiative (GRI) performance indicators disclosed in the nonfinancial reports produced by companies. Content analysis is a research technique frequently used in the literature to examine the extent of sustainability disclosures (Guthrie and Farneti 2008; Fonseca et al. 2011; Roca and Searcy 2012; Tarquinio et al. 2015). We focus our analysis on companies adopting the GRI standards because they are generally deemed as the most detailed and structured set of standards proposing analytical requirements for nonfinancial reporting information (Skouloudis et al. 2009). Moreover, GRI standards are the dominant global standards for reporting on nonfinancial information (KPMG 2020).The analysis is based on the reports published by Italian companies in 2013, 2016, and 2017 and the reports issued by Spanish companies in 2013, 2017, and 2018. We referred to different years considering the different timing of the EU Directive's transposition into Italian and Spanish regulations. Indeed, this study's primary purpose is to analyse the differences in disclosure levels before and after the publication of the Directive and its adoption into the two national legislations.

\subsection{Sample Selection}

As a starting sample, we selected the 40 Italian companies belonging to the FTSE MIB Index and the 35 Spanish companies included in the IBEX 35 Index updated to October 2019. The FTSE MIB Index consists of the most liquid and highly capitalised stocks listed on the Italian Stock Exchange, and the IBEX 35 Index is composed of the most liquid stocks traded on the Spanish Stock Exchange. Consequently, the comparison was made among the nonfinancial reporting practices of the most representative Italian and Spanish companies.

To evaluate the impact of the Directive on NFI disclosure, it was necessary to verify how many companies belonging to our sample fulfilled the requirements of Italian Decree 254/2016 and Spanish Law 11/2018 by producing a nonfinancial statement in 2017 (in the Italian case) and in 2018 (in the Spanish case). All Spanish companies in our sample published their nonfinancial statements following national law. However, this is not the case for the Italian sample. Consequently, 9 Italian companies were excluded from the analysis because their nonfinancial statements were not prepared in accordance with the Italian Decree. Therefore, the final sample consists of 35 Spanish companies and 31 Italian companies, for a total of 66 companies.

Figure 2 shows the 66 companies analysed, classified according to their industrial sector. Since the Italian and Spanish Stock Exchanges do not equally define all sectors, we subdivided companies using the Industry Structure and Definitions document provided by the Industry Classification Benchmark (ICB). Most companies belong to the financial sector, followed by the industrial and the oil \& gas sectors.

\subsection{Data Collection}

The analysis was carried out by collecting data from GRI-based NFI disclosures published by the sampled companies. To identify the performance indicators disclosed, we used the GRI Content Indexes attached to the nonfinancial reports or the websites. The GRI Content Index is a navigation tool that provides a complete, accurate, and transparent overview of the disclosures addressed in a GRI-based report by indicating the adoption and position of each GRI indicator (GRI 2012). 


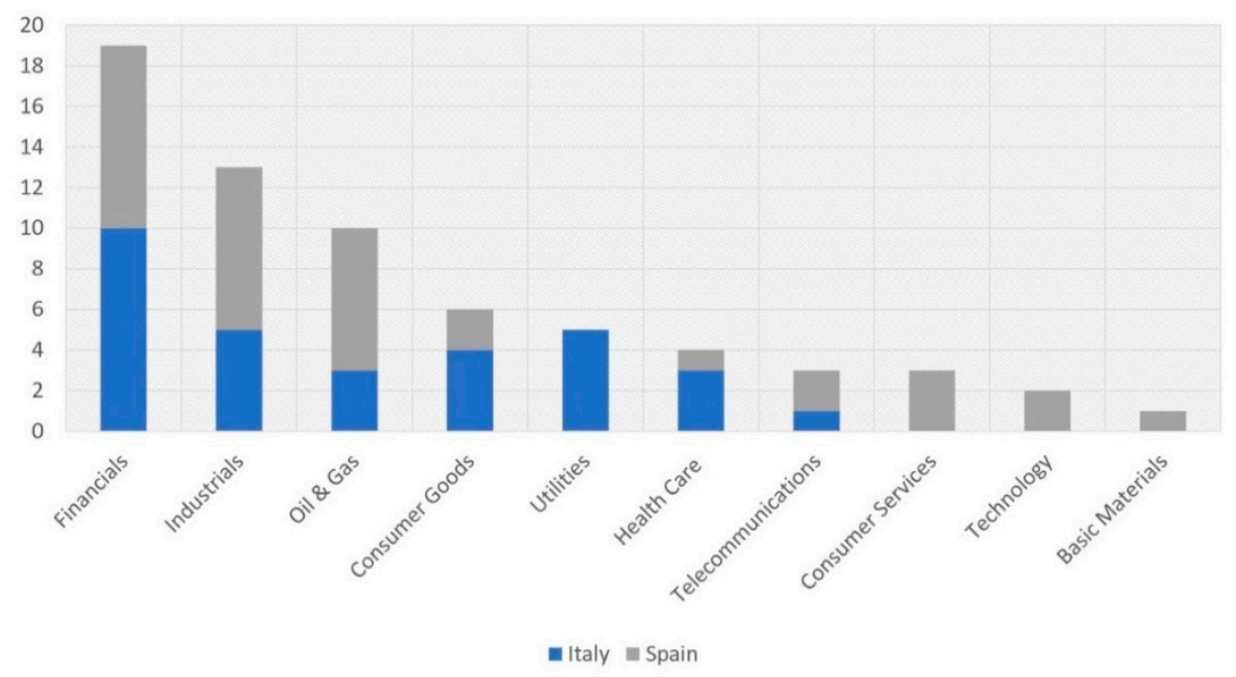

Figure 2. Classification of companies by sector and country.

However, it was not possible for some companies to find the GRI Index in the NFI report or on the company's website. Consequently, these companies were not considered in the analysis for the year in which the GRI Index was not available.

The companies used different versions of the GRI guidelines over the years analysed. As shown in Figure 3, in 2013, the companies used versions G3, G3.1, and G4. In 2016, 2017, and 2018, the G4 and GRI Standards were adopted.
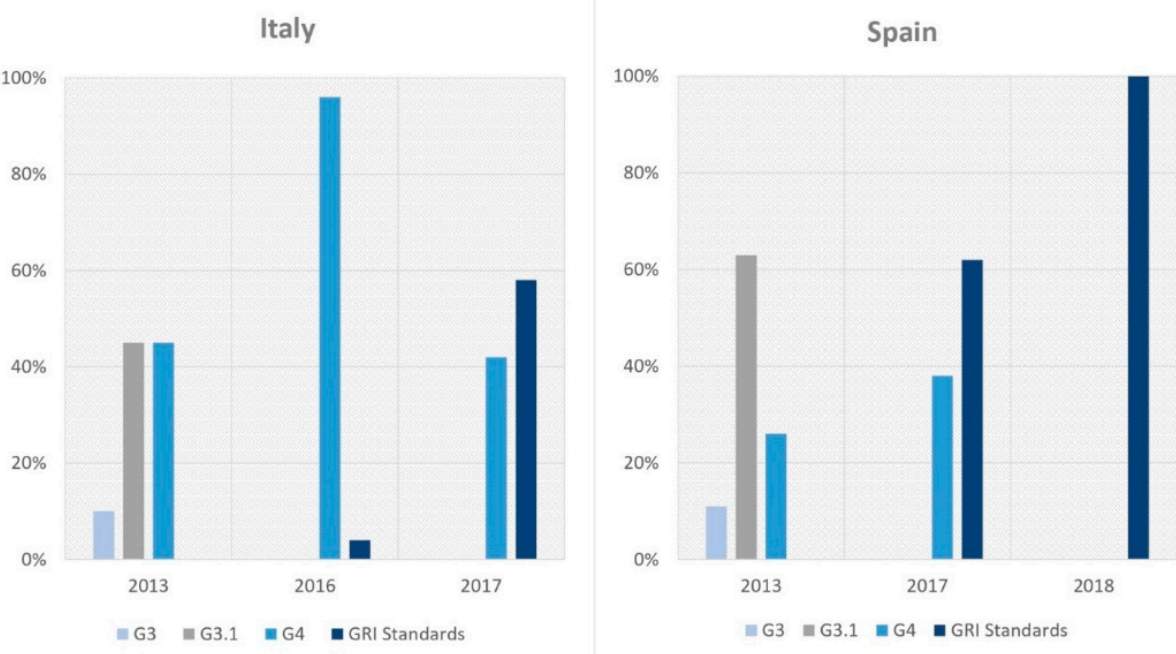

Figure 3. GRI guidelines adopted by companies over the years analysed.

The adoption of different GRI versions required the use of a conversion table (see Table 2). Indeed, the various ways in which indicators are named and organised would not have allowed us to carry out an objective and reliable comparison between the quantity of NFI disclosed before and after the regulatory intervention. Table 2 integrates the information in the GRI's three mapping tools to offer an overview of the changes in indicators that occurred from G3 to G3.1, from G3.1 to G4 and from G4 to GRI Standards (GRI 2012, 2013, 2017a). In line with the purposes of our analysis, Table 2 focuses on the new indicators introduced and on those deleted in the transition from one version to another. Moreover, the link between the G4 indicators and the GRI Standard disclosures is provided. Changes applied in terms of content and requirements were not taken into consideration in the conversion table. 
Table 2. Conversion table among versions of the GRI guidelines and GRI standards.

\begin{tabular}{|c|c|c|c|c|c|}
\hline \multirow{2}{*}{ Category } & \multirow{2}{*}{ Sub-Category } & \multicolumn{3}{|c|}{ GRI Guidelines Version } & \multirow[b]{2}{*}{ GRI Standards } \\
\hline & & G3 & G3.1 & G4 & \\
\hline \multirow{9}{*}{ Economic (EC) } & & EC1 & EC1 & G4-EC1 & $201-1$ \\
\hline & & $\mathrm{EC} 2$ & EC2 & G4-EC2 & $201-2$ \\
\hline & & EC3 & EC3 & G4-EC3 & $201-3$ \\
\hline & & $\mathrm{EC} 4$ & $\mathrm{EC} 4$ & G4-EC4 & $201-4$ \\
\hline & & EC5 & EC5 & G4-EC5 & $202-1$ \\
\hline & & EC6 & EC6 & G4-EC6 & $202-2$ \\
\hline & & EC7 & EC7 & G4-EC7 & 203-1 \\
\hline & & EC8 & EC8 & G4-EC8 & $203-2$ \\
\hline & & EC9 & EC9 & G4-EC9 & $204-1$ \\
\hline \multirow{34}{*}{$\begin{array}{l}\text { Environmental } \\
\text { (EN) }\end{array}$} & & EN1 & EN1 & G4-EN1 & $301-1$ \\
\hline & & EN2 & EN2 & G4-EN2 & $301-2$ \\
\hline & & EN3 & EN3 & G4-EN3 & $302-1$ \\
\hline & & EN4 & EN4 & G4-EN4 & $302-2$ \\
\hline & & EN5 & EN5 & G4-EN5 & $302-3$ \\
\hline & & EN6 & EN6 & G4-EN6 & $302-4$ \\
\hline & & EN7 & EN7 & G4-EN7 & $302-5$ \\
\hline & & EN8 & EN8 & G4-EN8 & $303-1$ \\
\hline & & EN9 & EN9 & G4-EN9 & $303-2$ \\
\hline & & EN10 & EN10 & G4-EN10 & $303-3$ \\
\hline & & EN11 & EN11 & G4-EN11 & $304-1$ \\
\hline & & EN12 & EN12 & G4-EN12 & $304-2$ \\
\hline & & EN13 & EN13 & G4-EN13 & $304-3$ \\
\hline & & EN14 & EN14 & G4-EN14 & $304-4$ \\
\hline & & EN15 & EN15 & G4-EN15 & $305-1$ \\
\hline & & EN16 & EN16 & G4-EN16 & $305-2$ \\
\hline & & EN17 & EN17 & G4-EN17 & $305-3$ \\
\hline & & EN18 & EN18 & G4-EN18 & $305-4$ \\
\hline & & EN19 & EN19 & G4-EN19 & $305-5$ \\
\hline & & EN20 & EN20 & G4-EN20 & $305-6$ \\
\hline & & EN21 & EN21 & G4-EN21 & $305-7$ \\
\hline & & EN22 & EN22 & G4-EN22 & $306-1$ \\
\hline & & EN23 & EN23 & G4-EN23 & $306-2$ \\
\hline & & EN24 & EN24 & G4-EN24 & $306-3$ \\
\hline & & EN25 & EN25 & G4-EN25 & $306-4$ \\
\hline & & EN26 & EN26 & G4-EN26 & $306-5$ \\
\hline & & EN27 & EN27 & G4-EN27 & - \\
\hline & & EN28 & EN28 & G4-EN28 & $301-3$ \\
\hline & & EN29 & EN29 & G4-EN29 & $307-1$ \\
\hline & & EN30 & EN30 & G4-EN30 & - \\
\hline & & - & - & G4-EN31 & - \\
\hline & & - & - & G4-EN32 & $308-1$ \\
\hline & & - & - & G4-EN33 & $308-2$ \\
\hline & & - & - & G4-EN34 & - \\
\hline
\end{tabular}


Table 2. Cont.

\begin{tabular}{|c|c|c|c|c|c|}
\hline \multirow{2}{*}{ Category } & \multirow{2}{*}{ Sub-Category } & \multicolumn{3}{|c|}{ GRI Guidelines Version } & \multirow[b]{2}{*}{ GRI Standards } \\
\hline & & G3 & G3.1 & G4 & \\
\hline \multirow{48}{*}{ Social (SOC) } & \multirow{16}{*}{ LA } & LA1 & LA1 & G4-LA1 & $401-1$ \\
\hline & & LA2 & LA2 & G4-LA2 & $401-2$ \\
\hline & & LA3 & LA3 & G4-LA3 & $401-3$ \\
\hline & & LA4 & LA4 & G4-LA4 & $402-1$ \\
\hline & & LA5 & LA5 & G4-LA5 & $403-1$ \\
\hline & & LA6 & LA6 & G4-LA6 & $403-2$ \\
\hline & & LA7 & LA7 & G4-LA7 & $403-3$ \\
\hline & & LA8 & LA8 & G4-LA8 & $403-4$ \\
\hline & & LA9 & LA9 & G4-LA9 & $404-1$ \\
\hline & & LA10 & LA10 & G4-LA10 & $404-2$ \\
\hline & & LA11 & LA11 & G4-LA11 & $404-3$ \\
\hline & & LA12 & LA12 & G4-LA12 & $405-1$ \\
\hline & & LA13 & LA13 & G4-LA13 & $405-2$ \\
\hline & & LA14 & LA14 & G4-LA14 & $414-1$ \\
\hline & & - & LA15 & G4-LA15 & $414-2$ \\
\hline & & - & - & G4-LA16 & - \\
\hline & \multirow{12}{*}{ HR } & HR1 & HR1 & G4-HR1 & $412-3$ \\
\hline & & HR2 & HR2 & G4-HR2 & $412-2$ \\
\hline & & HR3 & HR3 & G4-HR3 & $406-1$ \\
\hline & & HR4 & HR4 & G4-HR4 & $407-1$ \\
\hline & & HR5 & HR5 & G4-HR5 & 408-1 \\
\hline & & HR6 & HR6 & G4-HR6 & 409-1 \\
\hline & & HR7 & HR7 & G4-HR7 & $410-1$ \\
\hline & & HR8 & HR8 & G4-HR8 & $411-1$ \\
\hline & & HR9 & HR9 & G4-HR9 & $412-1$ \\
\hline & & - & HR10 & G4-HR10 & $414-1$ \\
\hline & & - & HR11 & G4-HR11 & $414-2$ \\
\hline & & - & - & G4-HR12 & - \\
\hline & \multirow{11}{*}{$\mathrm{SO}$} & SO1 & SO1 & G4-SO1 & $413-1$ \\
\hline & & $\mathrm{SO} 2$ & $\mathrm{SO} 2$ & G4-SO2 & $413-2$ \\
\hline & & $\mathrm{SO} 3$ & $\mathrm{SO} 3$ & G4-SO3 & $205-1$ \\
\hline & & $\mathrm{SO} 4$ & $\mathrm{SO} 4$ & G4-SO4 & $205-2$ \\
\hline & & SO5 & SO5 & G4-SO5 & $205-3$ \\
\hline & & SO6 & SO6 & G4-SO6 & $415-1$ \\
\hline & & SO7 & SO7 & G4-SO7 & 206-1 \\
\hline & & $\mathrm{SO} 8$ & SO8 & G4-SO8 & $419-1$ \\
\hline & & - & SO9 & G4-SO9 & 414-1 \\
\hline & & - & SO10 & G4-SO10 & $414-2$ \\
\hline & & - & - & G4-SO11 & - \\
\hline & \multirow{9}{*}{ PR } & PR1 & PR1 & G4-PR1 & $416-1$ \\
\hline & & PR2 & PR2 & G4-PR2 & $416-2$ \\
\hline & & PR3 & PR3 & G4-PR3 & $417-1$ \\
\hline & & PR4 & PR4 & G4-PR4 & $417-2$ \\
\hline & & PR5 & PR5 & G4-PR5 & - \\
\hline & & PR6 & PR6 & G4-PR6 & - \\
\hline & & PR7 & PR7 & G4-PR7 & $417-3$ \\
\hline & & PR8 & PR8 & G4-PR8 & $418-1$ \\
\hline & & PR9 & PR9 & G4-PR9 & 419-1 \\
\hline
\end{tabular}

Specifically, to verify the quantity and typology of NFI reported by companies, we considered the sustainability performance indicators included in Part 2 Standard Disclosures of the G3 and G3.1, in the Specific Standard Disclosures section of the G4 and in the Topicspecific Standards (200, 300 and 400 series) of the GRI Standards. In all four versions, these indicators are classified into Economic (EC), Environmental (EN), and Social (SOC) categories. In the G3, G3.1, and G4, social indicators are further subdivided into four 
subcategories: labour practices and decent work (LA), human rights (HR), society (SO), and product responsibility (PR). The conversion table also allowed us to apply this classification to the GRI Standards.

We checked for the presence or absence of the NFI reports' assurance before and after adopting the EU Directive. We gathered information about assurance providers, standards adopted, and the level of assurance by the companies' assurance statements over the years observed.

\subsection{Disclosure Index}

The level of NFI disclosure was scored using the disclosure index proposed by Cooke (1989). The disclosure index methodology consists of calculating the number of information-related items in a report based on a predefined list of the total items that could be disclosed (Cooke 1989). Consequently, the first step in the construction of the disclosure index was the selection of items. As mentioned above, the index applied in this analysis included items based on GRI performance indicators. Numerous studies have adopted GRI indicators to measure the amount of disclosure (Guthrie and Farneti 2008; Roca and Searcy 2012; Tarquinio et al. 2018). The indicators we considered in developing the NFI disclosure index are presented in Table 2.

Subsequently, it was necessary to establish rules for coding the data. To this aim, we followed a dichotomous procedure where " 1 " was assigned if an indicator was fully or partially disclosed and " 0 " if absent. We used an unweighted approach where each indicator was deemed equally important (Cooke 1989) to reduce the possible bias resulting from a subjective weighting (Raffournier 1995). To ensure the reliability and consistency of the analysis, GRI indexes were verified by two separate researchers. For the collection of the data, an excel sheet was prepared. The researchers compared the data collected with reference to a sample of 10 nonfinancial reports under investigation. Then, the data were compared, and the discrepancies found were discussed, leading to an adjustment of the data collection form. The final dataset was then built.

The disclosure index was obtained by dividing the number of GRI indicators disclosed by a company in the nonfinancial report by the GRI's total number of indicators. Formally:

$$
\begin{aligned}
& M=\sum_{i=1}^{n} d_{i} \\
& D I_{j}=\frac{M}{n}
\end{aligned}
$$

where

$M=$ number of GRI indicators disclosed by company $j, M \leq n$

$d_{i}=(" 1$ " if the GRI indicator was disclosed $)$

("0" if the GRI indicator was not disclosed)

$n=$ total number of GRI indicators

$D I_{j}=$ disclosure index for company $j, 0 \leq D I_{j} \leq 1$

As shown in Table 2, the economic (EC), environmental (EN), and social (SOC) categories contain different numbers of GRI indicators, which depends on the version of the GRI guidelines used by the company. Consequently, in formulas (1) and (2), the total number of indicators a company is expected to report (n) varies according to the category under consideration and the GRI version adopted (see Table 3).

To understand the effects of Directive 2014/95/UE, we calculated the index and the descriptive statistics for each year under analysis, and then we compared the results obtained over time. 
Table 3. Number of GRI indicators (n) by category and GRI version.

\begin{tabular}{ccccc}
\hline GRI Category & G3 & G3.1 & G4 & GRI Standards \\
\hline ECONOMIC (EC) & 9 & 9 & 9 & 9 \\
ENVIRONMENTAL (EN) & 30 & 30 & 34 & 30 \\
Labour Practices (LA) & 14 & 15 & 16 & 13 \\
Human Rights (HR) & 9 & 11 & 12 & 9 \\
Society (SO) & 8 & 10 & 11 & 10 \\
Product Responsibility (PR) & 9 & 9 & 9 & 6 \\
SOCIAL (SOC) & 40 & 45 & 48 & 38 \\
TOTAL & 79 & 84 & 91 & 77 \\
\hline
\end{tabular}

\section{Results}

Our study explored the evolution of NFI disclosure levels after the transposition of Directive 2014/95/EU into Italian and Spanish regulations by constructing a disclosure index. The disclosure index measured the extent of NFI disclosed based on the quantity of GRI indicators reported by the sampled companies before and after adopting the Directive. Indeed, the use of GRI indicators enables companies to meet all requirements of the new law by offering a full and balanced overview of their performance and the related impacts (GRI 2017b). To answer the first research question, we examined the effects of the EU legislation on overall economic, environmental, and social disclosure performance, focusing on indicator changes. Figure 4 introduces the disclosure analysis by showing the percentage of Italian and Spanish companies, sorted by industrial sector, that have produced a nonfinancial report over the three years analysed.
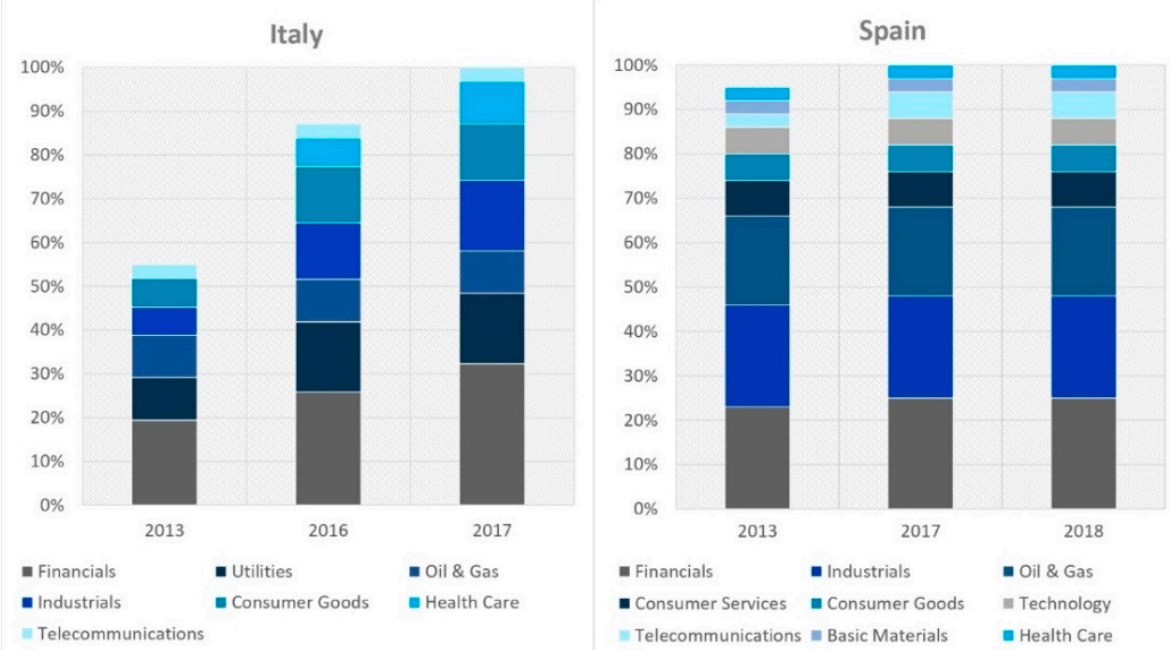

Figure 4. Evolution of experience in NFI disclosure by industrial sector.

Focusing on the years of experience gained by the sampled companies in NFI disclosure, EU regulation has significantly impacted Italy. In 2013, only $56 \%$ of Italian companies drew up a sustainability report, compared to $95 \%$ of Spanish companies. Moreover, a year before the EU law was implemented in national legislation, all Spanish companies had already published a nonfinancial report. In contrast, this percentage was reached in Italy until after the entry into force of Decree 254/2016. In both countries, the companies included in the financial sector were the most active in disclosing NFI since 2013, followed by companies belonging to the utilities sector in Italy and those belonging to the industrial sector in Spain. In Italy, the introduction of the Directive led to an increase in NFI disclosure practices mainly in the financial and health care sectors (from 19\% in 2013 to $32 \%$ in 2017 and from $0 \%$ to $10 \%$, respectively). In Spain, the financial and telecommunications sectors were the most influenced, presenting slight increases of $2 \%$ and $3 \%$, respectively. 


\subsection{Disclosure Index}

The disclosure index was calculated for each category and subcategory of indicators set by the GRI. Furthermore, a total disclosure index was obtained by considering the GRI indicators in the economic (EC), environmental (EN), and social (SOC) categories altogether. The disclosure index can take values from 0 to 1 . The higher the value assumed by the index is, the higher the level of NFI disclosed. Table 4 provides descriptive statistics on the Italian and Spanish samples' disclosure index before and after the EU Directive and its adoption into the respective legislations.

Table 4. Descriptive statistics on the disclosure index before and after Directive 2014/95/EU.

\begin{tabular}{|c|c|c|c|c|c|c|c|c|c|c|c|c|}
\hline & \multicolumn{6}{|c|}{ Italy } & \multicolumn{6}{|c|}{ Spain } \\
\hline & & Min & Max & Mean & SD & Mdn & & Min & Max & Mean & SD & Mdn \\
\hline \multirow{3}{*}{ EC } & 2013 & 0.56 & 1 & 0.86 & 0.17 & 0.89 & 2013 & 0 & 1 & 0.28 & 0.37 & 0.11 \\
\hline & 2016 & 0.11 & 1 & 0.57 & 0.28 & 0.56 & 2017 & 0 & 1 & 0.61 & 0.36 & 0.56 \\
\hline & 2017 & 0 & 1 & 0.42 & 0.31 & 0.44 & 2018 & 0 & 1 & 0.55 & 0.38 & 0.56 \\
\hline \multirow{3}{*}{ EN } & 2013 & 0.32 & 1 & 0.70 & 0.22 & 0.70 & 2013 & 0 & 1 & 0.33 & 0.29 & 0.13 \\
\hline & 2016 & 0.03 & 1 & 0.50 & 0.25 & 0.46 & 2017 & 0 & 1 & 0.56 & 0.38 & 0.57 \\
\hline & 2017 & 0 & 1 & 0.38 & 0.22 & 0.35 & 2018 & 0.03 & 1 & 0.52 & 0.35 & 0.43 \\
\hline \multirow{3}{*}{ SOC } & 2013 & 0.31 & 1 & 0.77 & 0.23 & 0.84 & 2013 & 0.06 & 1 & 0.36 & 0.30 & 0.31 \\
\hline & 2016 & 0.21 & 1 & 0.55 & 0.26 & 0.52 & 2017 & 0 & 1 & 0.59 & 0.35 & 0.57 \\
\hline & 2017 & 0.05 & 1 & 0.46 & 0.25 & 0.40 & 2018 & 0.03 & 1 & 0.52 & 0.34 & 0.47 \\
\hline \multirow{3}{*}{ LA } & 2013 & 0.56 & 1 & 0.92 & 0.13 & 1 & 2013 & 0 & 1 & 0.32 & 0.30 & 0.25 \\
\hline & 2016 & 0.06 & 1 & 0.68 & 0.25 & 0.69 & 2017 & 0 & 1 & 0.56 & 0.41 & 0.54 \\
\hline & 2017 & 0.15 & 1 & 0.58 & 0.24 & 0.54 & 2018 & 0 & 1 & 0.45 & 0.40 & 0.31 \\
\hline \multirow{3}{*}{ HR } & 2013 & 0 & 1 & 0.60 & 0.41 & 0.82 & 2013 & 0 & 1 & 0.39 & 0.31 & 0.33 \\
\hline & 2016 & 0 & 1 & 0.35 & 0.33 & 0.21 & 2017 & 0 & 1 & 0.68 & 0.36 & 0.89 \\
\hline & 2017 & 0 & 1 & 0.29 & 0.33 & 0.17 & 2018 & 0 & 1 & 0.61 & 0.37 & 0.67 \\
\hline \multirow{3}{*}{ SO } & 2013 & 0.18 & 1 & 0.83 & 0.26 & 0.91 & 2013 & 0 & 1 & 0.35 & 0.32 & 0.18 \\
\hline & 2016 & 0.09 & 1 & 0.60 & 0.30 & 0.55 & 2017 & 0 & 1 & 0.52 & 0.38 & 0.50 \\
\hline & 2017 & 0 & 1 & 0.46 & 0.29 & 0.36 & 2018 & 0 & 1 & 0.50 & 0.38 & 0.40 \\
\hline \multirow{3}{*}{ PR } & 2013 & 0 & 1 & 0.65 & 0.34 & 0.67 & 2013 & 0 & 1 & 0.37 & 0.37 & 0.44 \\
\hline & 2016 & 0 & 1 & 0.50 & 0.38 & 0.56 & 2017 & 0 & 1 & 0.66 & 0.38 & 0.75 \\
\hline & 2017 & 0 & 1 & 0.44 & 0.33 & 0.33 & 2018 & 0 & 1 & 0.56 & 0.37 & 0.50 \\
\hline \multirow{3}{*}{ TOT } & 2013 & 0.34 & 1 & 0.75 & 0.20 & 0.79 & 2013 & 0.08 & 1 & 0.34 & 0.28 & 0.26 \\
\hline & 2016 & 0.15 & 1 & 0.54 & 0.24 & 0.51 & 2017 & 0.03 & 1 & 0.58 & 0.35 & 0.56 \\
\hline & 2017 & 0.04 & 0.99 & 0.42 & 0.23 & 0.40 & 2018 & 0.04 & 1 & 0.52 & 0.33 & 0.48 \\
\hline
\end{tabular}

In 2013, although Spanish companies were more active than Italian companies in publishing sustainability reports (see Figure 4), the level of NFI disclosed by the former was significantly lower. GRI indicators were better represented in Italian companies' reports, with an average index equal to 0.86 for the economic category, followed by the social $(0.77)$ and environmental $(0.70)$ categories. The most disclosed social indicators were those related to labour practices, with an average of 0.92 . The EN and SOC indicators featured a higher standard deviation than the EC indicators, indicating greater contrast among companies in the reporting of environmental and social topics. Specifically, indicators about human rights had the highest standard deviation, equal to 0.41 . All categories had median values greater than the related mean, revealing that the number of indicators disclosed for each category by most of the Italian companies was higher than the average. Overall, the average value of 0.75 highlights a higher level of NFI disclosure among Italian companies than among Spanish companies, which, on average, achieved a total index of 0.34. In Spain, the social indicators were those more frequently reported, with an average index amounting to 0.36 and particular attention to indicators concerning human rights (0.39). Moreover, the least reported category was the economic category (0.28). Unlike 
the case in Italy, in Spain, the economic indicators had the lowest concentration around the average (standard deviation of 0.37). All categories had median values lower than their average values, except the indicators related to product responsibility, for which the opposite result was found.

In 2016, we registered a general decrease in the level of disclosure of Italian companies, which obtained, on average, a total index equal to 0.54 . This reduction involved all the indicator categories, especially the EC indicators. Nevertheless, compared with the EN and SOC categories, the economic category (with an average value of 0.57 ) was the most reported. It had the highest standard deviation (0.28), suggesting a greater dispersion among Italian companies in the disclosure of these indicators. Indicators regarding labour practices, with an average index of 0.68 , represented the most general social category and, together with indicators related to product responsibility, were the only ones that still had median values higher than the average.

In contrast to the Italian case, in 2017, the average index increased in all categories disclosed by Spanish companies, resulting in a total average value of 0.58 . The indicators presenting the greatest increase were those related to $\mathrm{EC}$, representing the most common category, with an average value of 0.61 . Particularly interesting are the values assumed by indicators related to human rights. In Italy, these indicators were less frequently disclosed before the new law (average index of 0.35). In contrast, in Spain, they represented, on average, the most mentioned social category (0.68). They presented the widest gap between the average (0.68) and the median (0.89) values, signalling less symmetry in their distribution. Moreover, a considerable difference among Spanish companies in reporting the EN indicators is suggested by a standard deviation of 0.38 .

After the adoption of Decree 254/2016, Italian companies further reduced the amount of NFI disclosed in all categories, achieving, on average, a total index equal to 0.42 . EC indicators, with an average index of 0.42 , were the most diminished over the previous year and constitute the only category for which the median value exceeds the average, with the smallest gap between the two values ( 0.44 and 0.42 , respectively). The SOC category had the highest average index (0.46), and indicators related to labour practices were again the most cited social indicators (0.58). Insufficient attention continued to be paid to human rights indicators, which presented, on average, an index of 0.29 . The environmental category featured a larger concentration around the average value (standard deviation of 0.22 ). The economic category, on the other hand, had the largest standard deviation (0.31). With the entry into force of Royal Decree-Law 18/2017, Spanish companies reduced their levels of NFI disclosure compared to the previous year, but they maintained a higher level than 2013 (with a total index amounting to an average of 0.52). This applied to all categories of indicators and notably to the social category, whose index decreased from 0.59 in 2017 to 0.52 in 2018. A significant reduction can be seen for indicators concerning labour practices, from 0.56 to 0.45 . In addition, these indicators have the largest difference between the average value (0.45) and the median (0.31). The most disclosed category is still related to EC, with an average index of 0.55 and the highest standard deviation (0.38) compared with the EN and SOC categories, for which the values of the average index ( 0.52 in both cases) and the standard deviation ( 0.35 and 0.34 , respectively) are very similar.

Figures 5 and 6 show, by industrial sector, the average trends of the total disclosure indexes of Italy and Spain, respectively, throughout the analysed years.

In Italy, the highest levels of NFI disclosure over the period studied were reached by companies belonging to the consumer goods and utilities sectors, except in 2017, when the only company in the telecommunications sector obtained the highest index. Companies in the health care sector presented the lowest average values of disclosure. The overall level of disclosure decreased in most of the sectors analysed, except for the telecommunications and health care sectors, where the later adoption of NFI reporting practices is associated with an average increase in the total index. Moreover, very similar trends are documented between the industrial and financial sectors. 


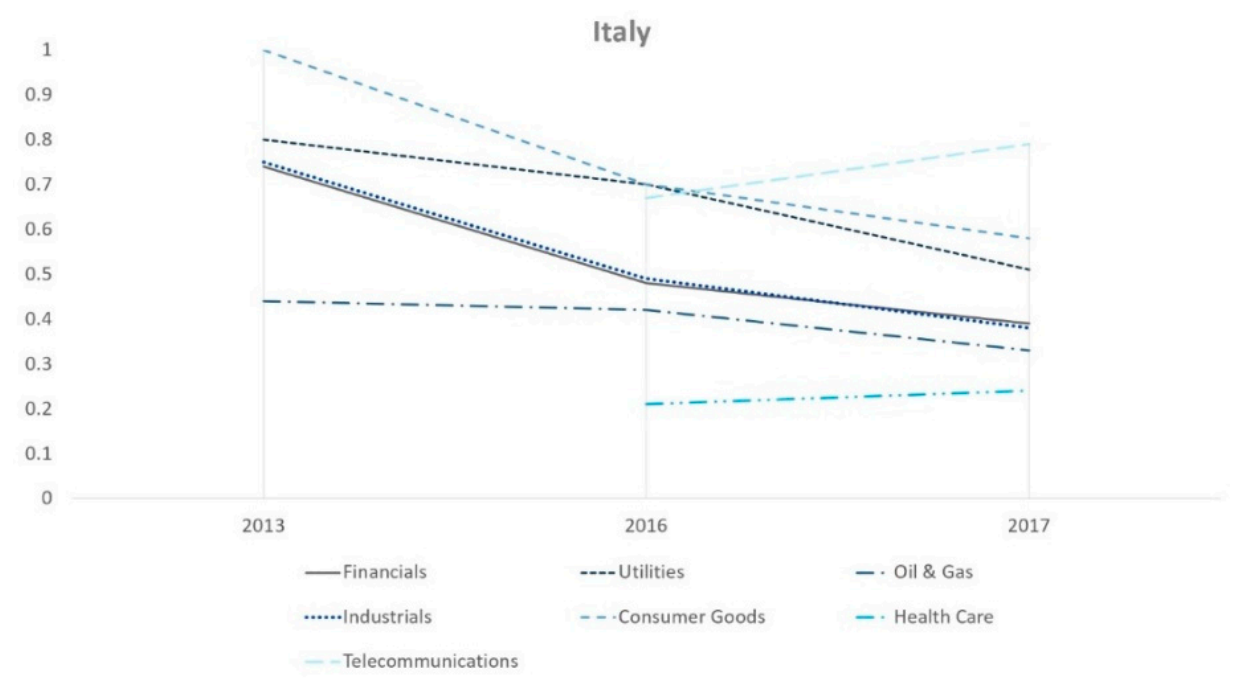

Figure 5. Total disclosure index by industrial sector in Italy.

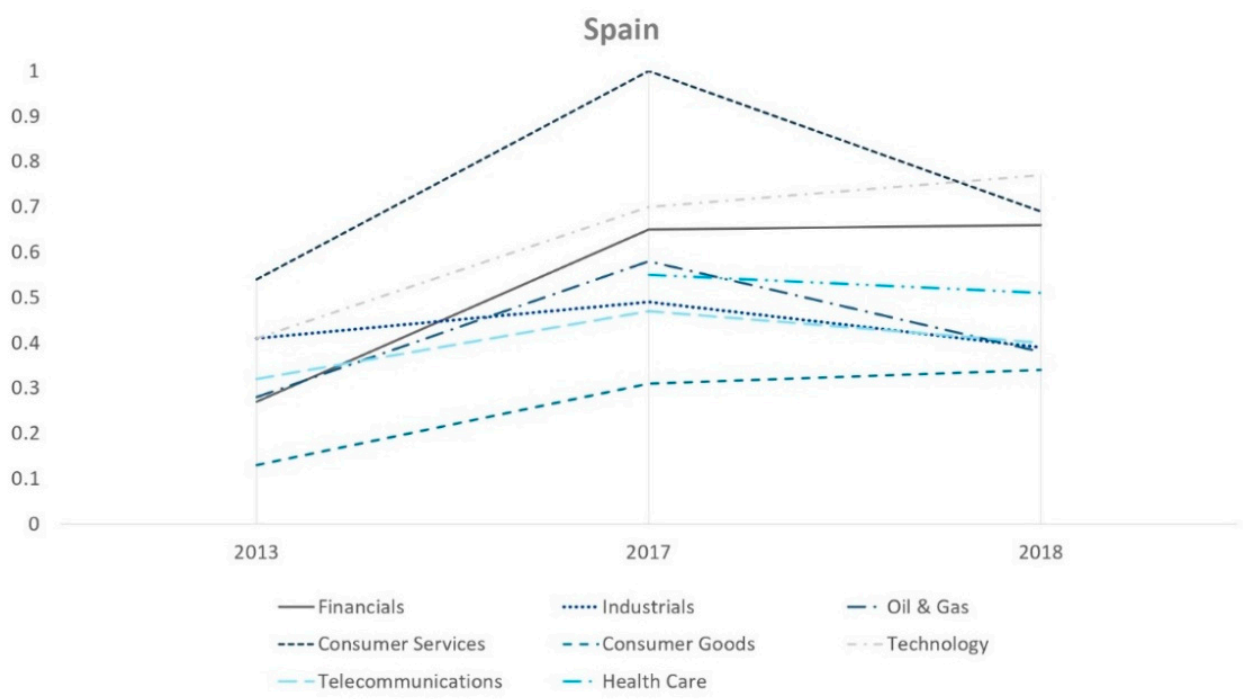

Figure 6. Total disclosure index by industrial sector in Spain.

In Spain, the highest number of total indicators was reported in the consumer services and technology sectors, while the lowest number was reported in the consumer goods sector. The same trend identified in Table 4 was registered for most sectors, except for the technology, financial, and consumer goods sectors, where the average value of the total index steadily increased. As in the Italian case, we observed that the health care sector began to disclose NFI only after the Directive's publication.

To strengthen the validity of the results, we have compared NFI disclosure levels before and after the adoption of the EU Directive using a t-test. The t-test analysis aims to determine whether the differences between disclosure levels are statistically significant. As shown in Table 5, significant differences in Italian disclosure levels are found between 2013 and 2016, 2013 and 2017 (significant at the 1\% level), and between 2016 and 2017 (significant at the $5 \%$ level). Our results also reveal significant differences in Spanish disclosure levels between 2013 and 2017, and between 2013 and 2018 (significant at the 1\% level). The differences observed in disclosure levels of Spanish companies between 2017 and 2018 were instead statistically insignificant. This may be due to the two-steps process by which the transposition of the Directive took place in this country. 
Table 5. T-test results.

\begin{tabular}{cccc}
\hline \multirow{3}{*}{ Italy } & & \multicolumn{1}{c}{$\boldsymbol{T}$} & $\boldsymbol{p}$-Value \\
\hline \multirow{3}{*}{ Spain } & 2013 vs. 2016 & 2.832 & 0.005 \\
\cline { 2 - 4 } & 2013 vs. 2017 & 4.481 & 0.001 \\
\cline { 2 - 4 } & 2016 vs. 2017 & 1.742 & 0.044 \\
\cline { 2 - 4 } & 2013 vs. 2017 & -2.909 & 0.003 \\
\cline { 2 - 4 } & 2013 vs. 2018 & -2.294 & 0.010 \\
\hline \multirow{2}{*}{ S2017 vs. 2018} & 0.739 & 0.231 \\
\hline
\end{tabular}

\subsection{The Disclosure of GRI Indicators before and after the Directive 2014/95/EU}

The second research question was addressed by investigating the changes in the quantity of NFI produced by the EU Directive referring to each GRI indicator. To this end, the disclosure index was calculated by dividing the number of companies that disclosed the GRI indicator under consideration by the total number of companies included in our sample that published a nonfinancial report in the same year.

\subsubsection{GRI Economic Indicators}

The economic dimension of sustainability relates to a company's impact on stakeholders' economic conditions and on economic systems at the local and global levels. Consequently, the economic category of GRI indicators provides information on the creation and distribution of economic value and supports the understanding of whether and how companies create wealth for their stakeholders (GRI 2016).

In Italy, we observed a progressive decrease in the disclosure of all EC indicators over the years studied (see Figure 7). In 2013, all economic indicators were reported by more than half of the Italian companies, while in 2017, this was the case only for the indicator providing information on the economic value generated and distributed (EC1; 201-1). This last indicator, together with the indicator related to the indirect economic impacts $(E C 7 ; 203-1)$, was the most reported before and after the Directive's implementation. Previous studies have explained the extensive use of this indicator with the greater availability of related data in corporate accounting systems (Tarquinio et al. 2018; Raucci and Tarquinio 2020). In contrast, the indicator relating to market presence (EC5; 202-1) was always the least communicated within its category. Moreover, the indicator referring to benefit plan obligations and other retirement plans (EC3; 201-3) suffered the most significant reduction, with an index equal to 1 in 2013 and 0.4 in 2017.

As shown in Figure 8, in 2017, we detected an increase in all the EC indicators reported by Spanish companies, followed by a general decrease in 2018 . The increase especially involved the indicator related to the proportion of senior management hired from the local community (EC6; 202-2), while in 2018, the index diminished in approximately equal measure for all indicators. Interestingly, the use of the EC indicators differs significantly between Spanish and Italian companies. Indeed, different from the case for Italian companies, the indicator concerning market presence (EC5; 202-1) was always the most reported by Spanish companies, and the indicator referring to the economic value generated and distributed (EC1; 201-1) was the least reported in 2017 and 2018. 


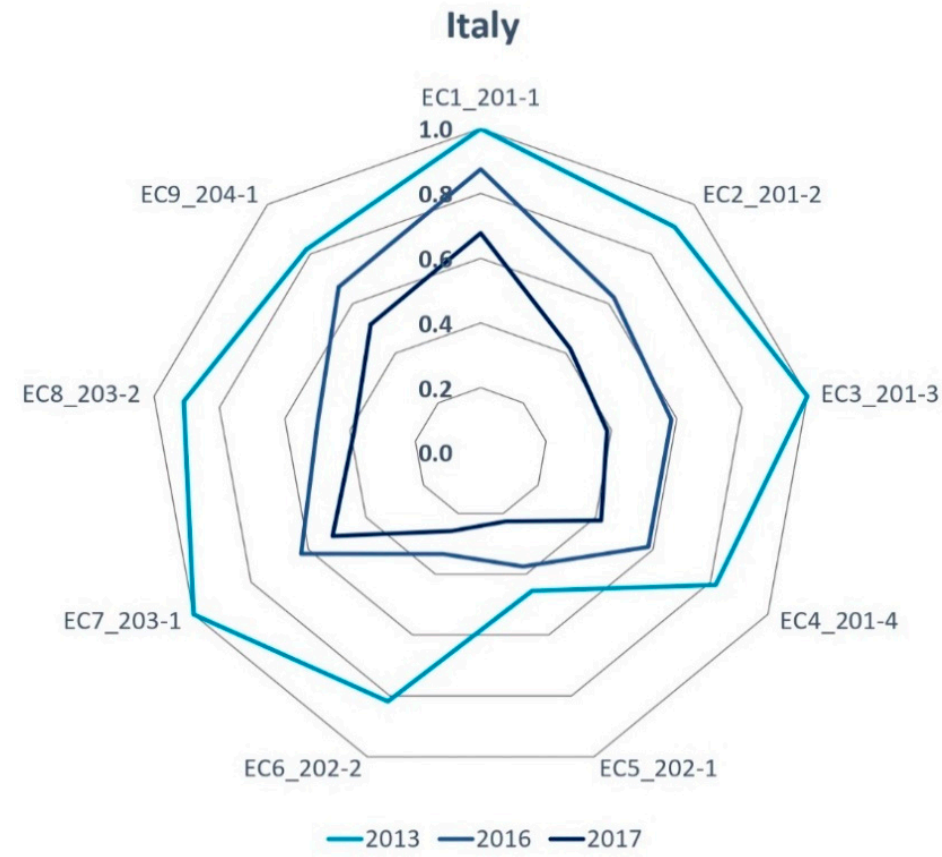

Figure 7. The use of the GRI economic indicators in Italy.

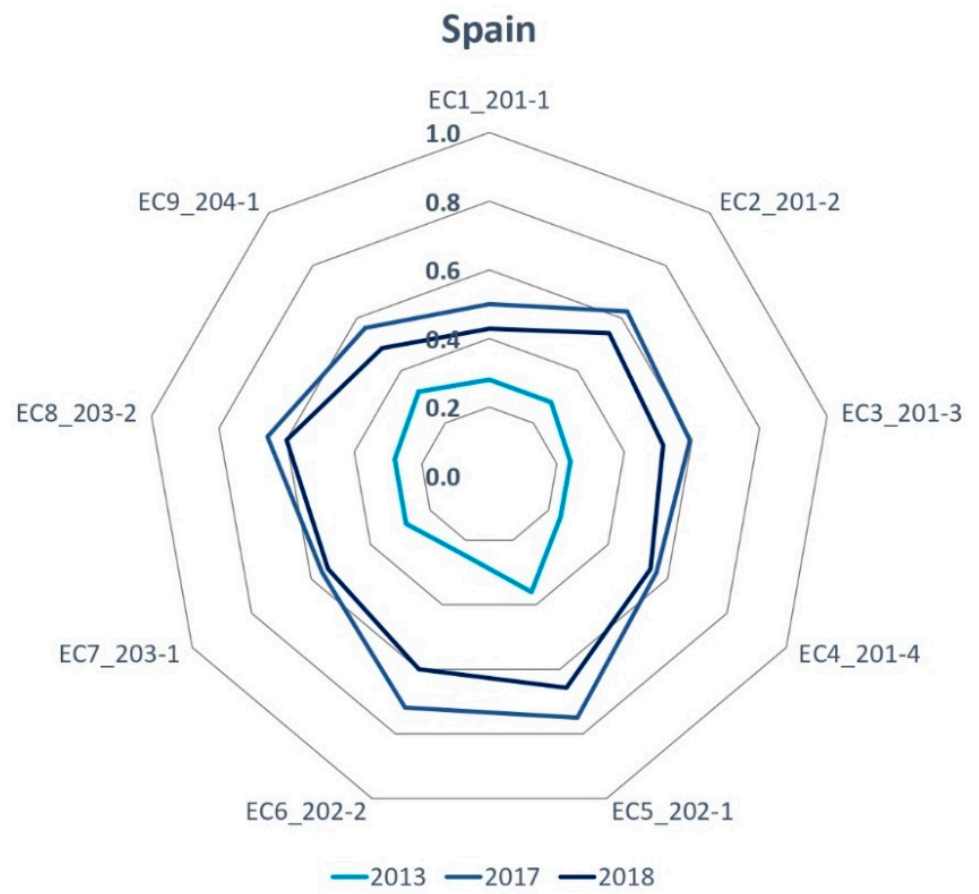

Figure 8. The use of the GRI economic indicators in Spain.

\subsubsection{GRI Environmental Indicators}

Companies can use the GRI category of environmental indicators to report information about the impacts generated by corporate activity on living and nonliving natural systems and how these impacts are managed (GRI 2016). Specifically, in the context of the EU Directive, companies are required to disclose energy consumption; discharge of emissions into the atmosphere; water withdrawal, use, and discharge; land use and biodiversity protection; use of materials; and contributions to resource conservation (GRI 2017b).

Figure 9 shows the reduction of almost all the environmental indicators in the reporting by Italian companies. However, the indicators related to greenhouse gas (GHG) emissions (EN15; 305-1) and to the management of waste-related impacts (EN23; 306-2) increased 
from 0.5 in 2013 to 0.9 and 0.8 in 2017, respectively. The disclosure index notably decreased for the indicator of energy consumption outside of the organisation (EN4; 302-2), with values of 0.9 in 2013 and 0.2 in 2017, and for the indicator related to wastes directed to disposal (EN26; 306-5), from 0.8 to 0.1 . The most-reported environmental indicators concerned, both before and after the Directive, energy and emissions aspects (EN3;302-1, EN5;302-3, EN15;305-1, EN16;305-2). In 2013, the least communicated indicators were those relating to the supplier environmental assessment (EN32;308-1, EN33;308-2), while in 2017, they referred to biodiversity and waste disposal issues (EN12;304-2, EN13;304-3, EN14;304-4, EN25;306-4, EN26;306-5).

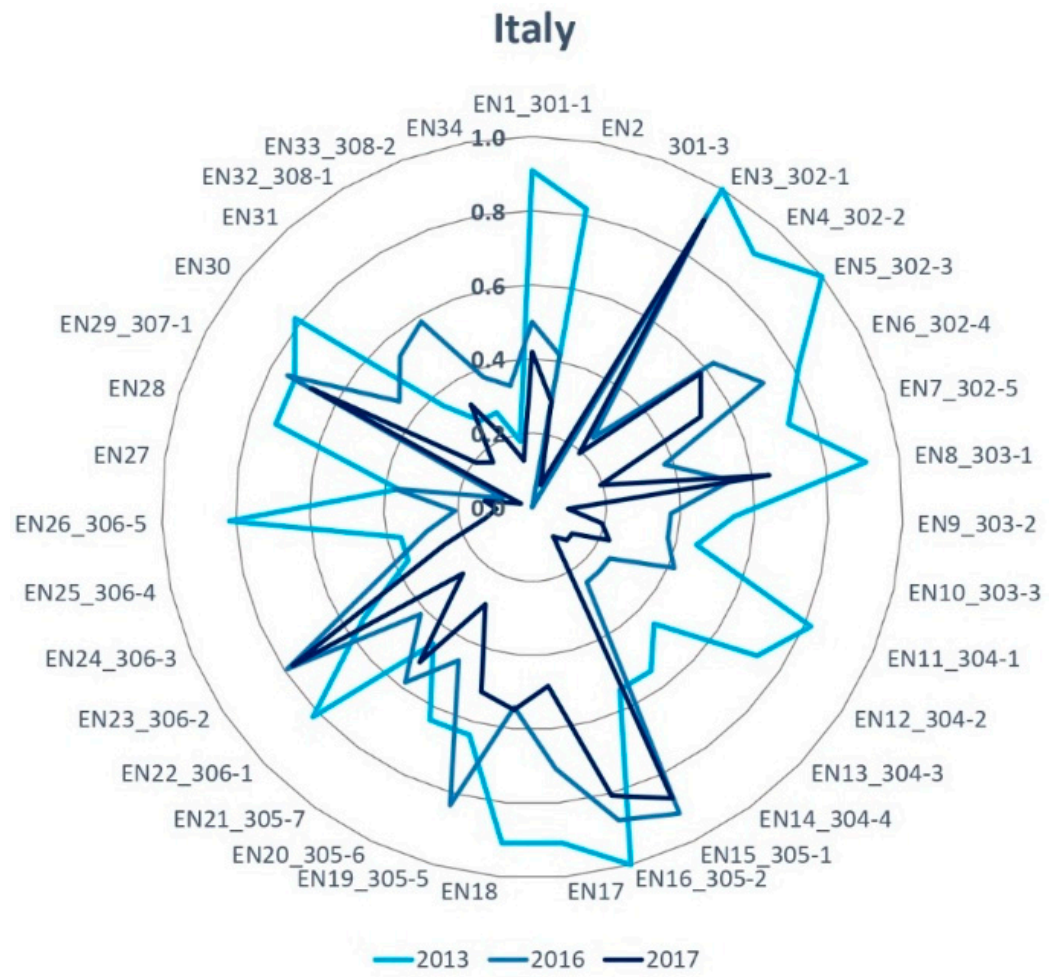

Figure 9. The use of the GRI environmental indicators in Italy.

Spanish companies differ significantly from Italian companies in the disclosure of environmental topics (see Figure 10). In 2017, the index increased for almost all the environmental indicators. A larger rise was found for indicators related to the use of materials (EN1; 301-1), biodiversity (EN11; 304-1, EN12; 304-2), and waste disposal (EN26; 306-5), from 0.2 in 2013 to 0.6 in 2017 and 2018. Compared with the general trend shown in Table 4, for most of the environmental indicators, the index did not decrease after the transposition of the Directive, but it maintained the same value achieved the previous year. In 2013, indicators relating to the supplier environmental assessment were among those most used by Spanish companies, with an index amounting to 0.7. After the Directive, they mainly focused on reporting materials, water, biodiversity, and waste topics, whose respective indicators obtained index values between 0.5 and 0.6 . Indicators concerning energy consumption (EN3; 302-1, EN4; 302-2) and emissions (EN16; 305-2, EN19; 305-5, EN20; 305-6, EN21; 305-7) were among the least reported in 2013, with an index of 0.2. In 2018, less attention continued to be paid to specific energy and emissions aspects, such as energy intensity and reduction in its consumption (EN5; 302-3, EN6; 302-4) and direct GHG emissions (EN15; 305-1), whose indexes were equal to 0.4 . 


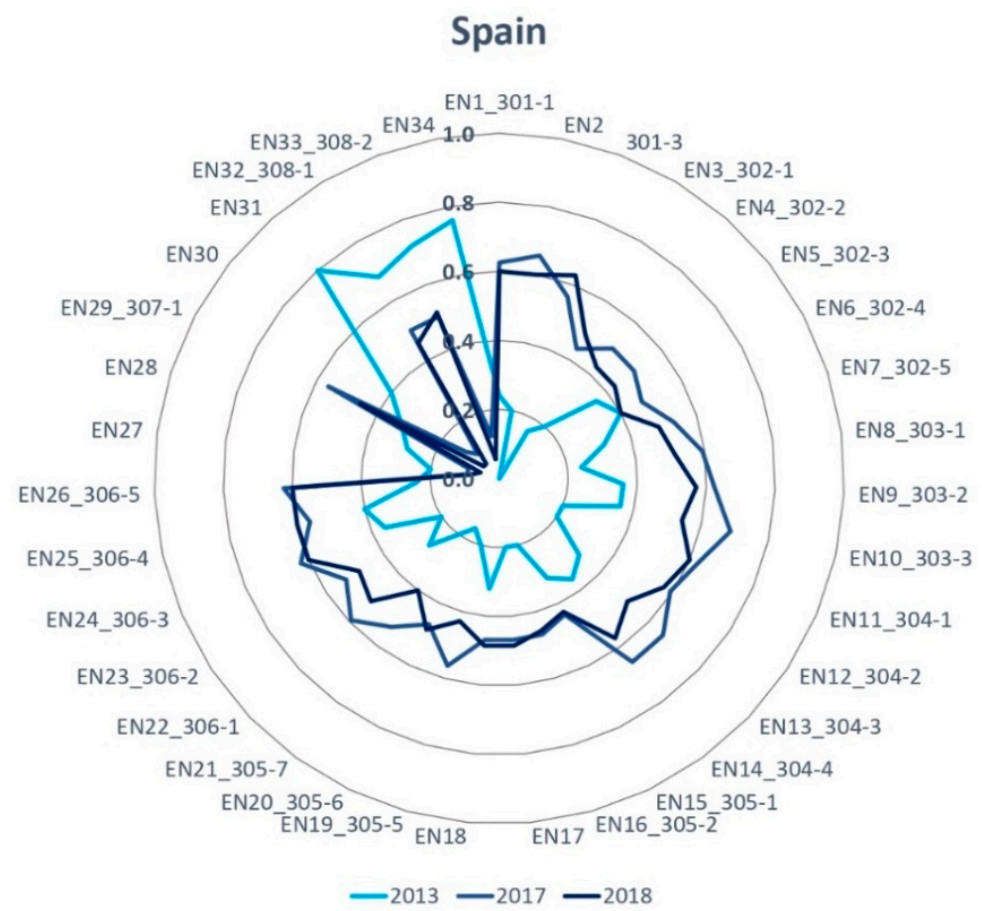

Figure 10. The use of the GRI environmental indicators in Spain.

\subsubsection{GRI Social Indicators}

The GRI social indicators concern companies' effects on the social systems within which they operate (GRI 2016). Companies can adopt these indicators to respond to regulatory requirements on the disclosure of information related to the relationship with local communities, respect for human rights, employment, and working conditions (GRI 2017b).

Figure 11 shows the ongoing decrease that, over the years, characterised all the social indicators disclosed by Italian companies, except for those referring to grievance mechanisms in the areas of human rights (HR12), labour practices (LA16) and impacts on society (SO11), which first increased in 2016 and then decreased in 2017. The greatest reduction was found in the use of the indicators relating to occupational health services (LA7; 403-3), from 0.9 in 2013 to 0.2 in 2017, and to worker participation in occupational health and safety matters (LA8; 403-4), from 1 to 0.3 . In 2013, indicators about labour practices and society were among the most common social indicators. In particular, the highest value of the index (equal to 1 ) was achieved by the indicators referring to employment (LA1; 401-1, LA2; 401-2), occupational health and safety (LA6; 403-2, LA8; 403-4), training and education (LA9; 404-1), socioeconomic compliance (SO8; 419-1), and communication and training about anticorruption (SO4; 205-2). In 2017, indicators on labour practices remained the most communicated, with an index of 0.9 for the indicators LA1; 401-1 and LA9; 404-1. Before and after the regulatory intervention, indicators related to human rights issues were among the least disclosed. Specifically, indicator HR12 was the least reported in 2013, and the indicator referring to security practices (HR7; 410-1) was the least reported in 2017 (both with a value of 0.1 ). These results are in accordance with the results of previous studies that analysed the use of GRI indicators in Italy (Tarquinio et al. 2018, 2020). 

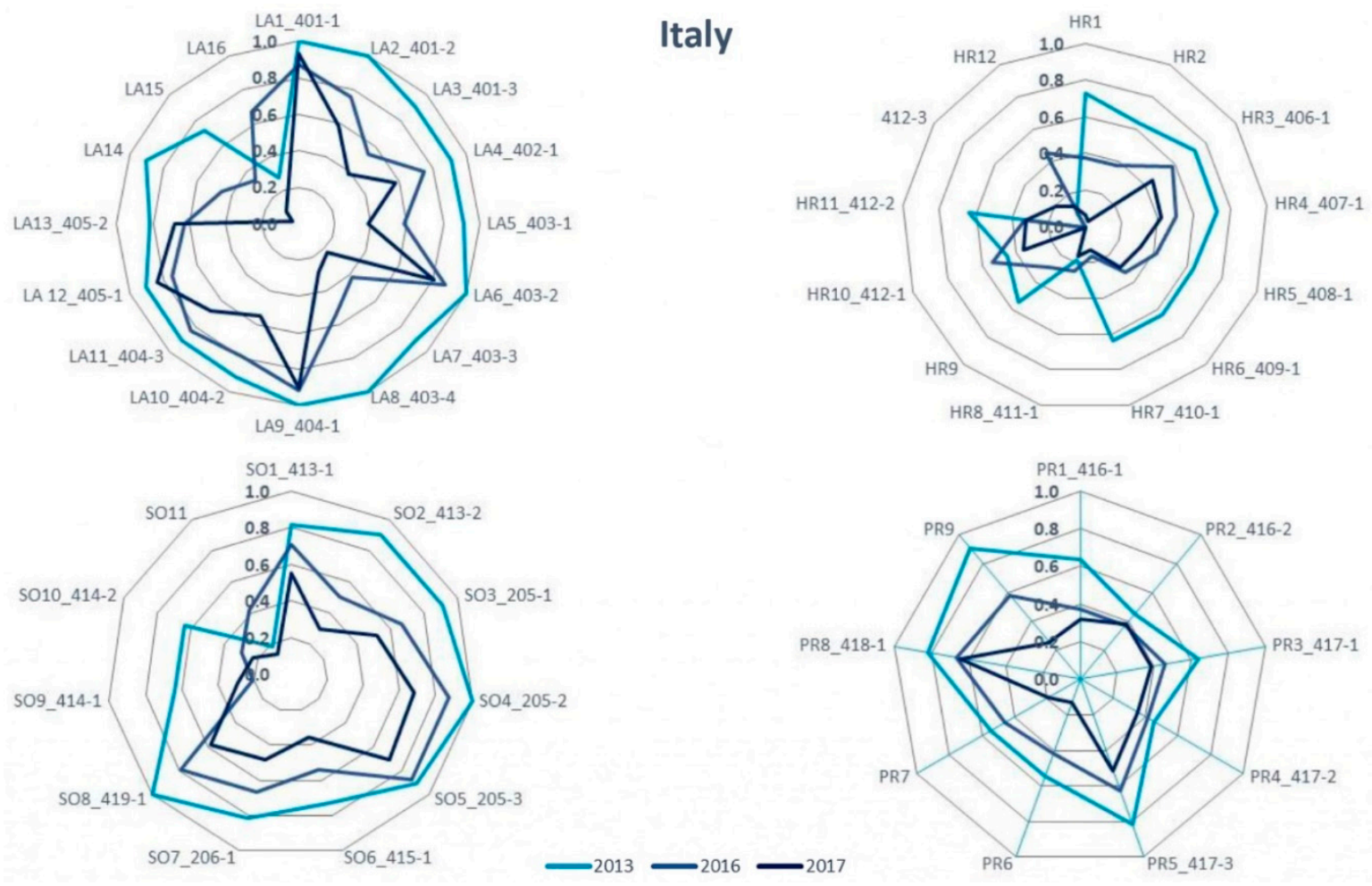

Figure 11. The use of the GRI social indicators in Italy.

In line with the trend identified in Table 4, we first registered an expansion in the adoption of social indicators by Spanish companies, followed by a slight reduction in 2018 (see Figure 12). However, this did not occur for most indicators relating to society, whose indexes maintained, in 2018, the same value achieved before the implementation of the Directive into national law. Unlike the case in Italy, and consistent with Gallego (2006), in 2017, we found that Spanish companies gave higher attention to indicators concerning human rights, such as HR4; 407-1, HR5; 408-1, and HR6; 409-1. In 2018, the largest reduction involved the indicator related to customer policy (PR8; 418-1), from 0.65 in 2017 to 0.4 . In 2013, the most reported social indicators were LA16, HR12 and SO11 (index of 0.7). In 2018, the highest values were reached for the indicator about the rights of indigenous peoples (HR8; 411-1) and the indicator concerning incidents of non-compliance in marketing communication (PR5; 417-3). The least disclosed social indicators largely pertained, over the whole period analysed, to the topic of labour practices. The indicators regarding employee hire and turnover (LA1; 401-1), parental leave (LA3; 401-3), and worker representation (LA5; 403-1) were among the least commonly used indicators both before and after the introduction of mandatory NFI disclosure.

\subsection{Assurance Practices of NFI}

To answer the third research question, we verified the differences in the adoption of assurance practices and, where already applied, in their characteristics before and after the introduction of the NFI Directive (see Table 6). The number of companies that assured their NFI reports grew in both Italy and Spain after the transposition of the Directive into the two national regulations. The mandatory provision of assurance is a coercive force that has produced a relevant impact on assurance dissemination. Accounting assurance providers (AAPs) dominate the assurance market of NFI in both Italy and Spain, similar to the results presented in other studies on the assurance of NFI (KPMG 2008; Kolk 2010; Romero et al. 2010; Martínez-Ferrero and García-Sánchez 2018). 


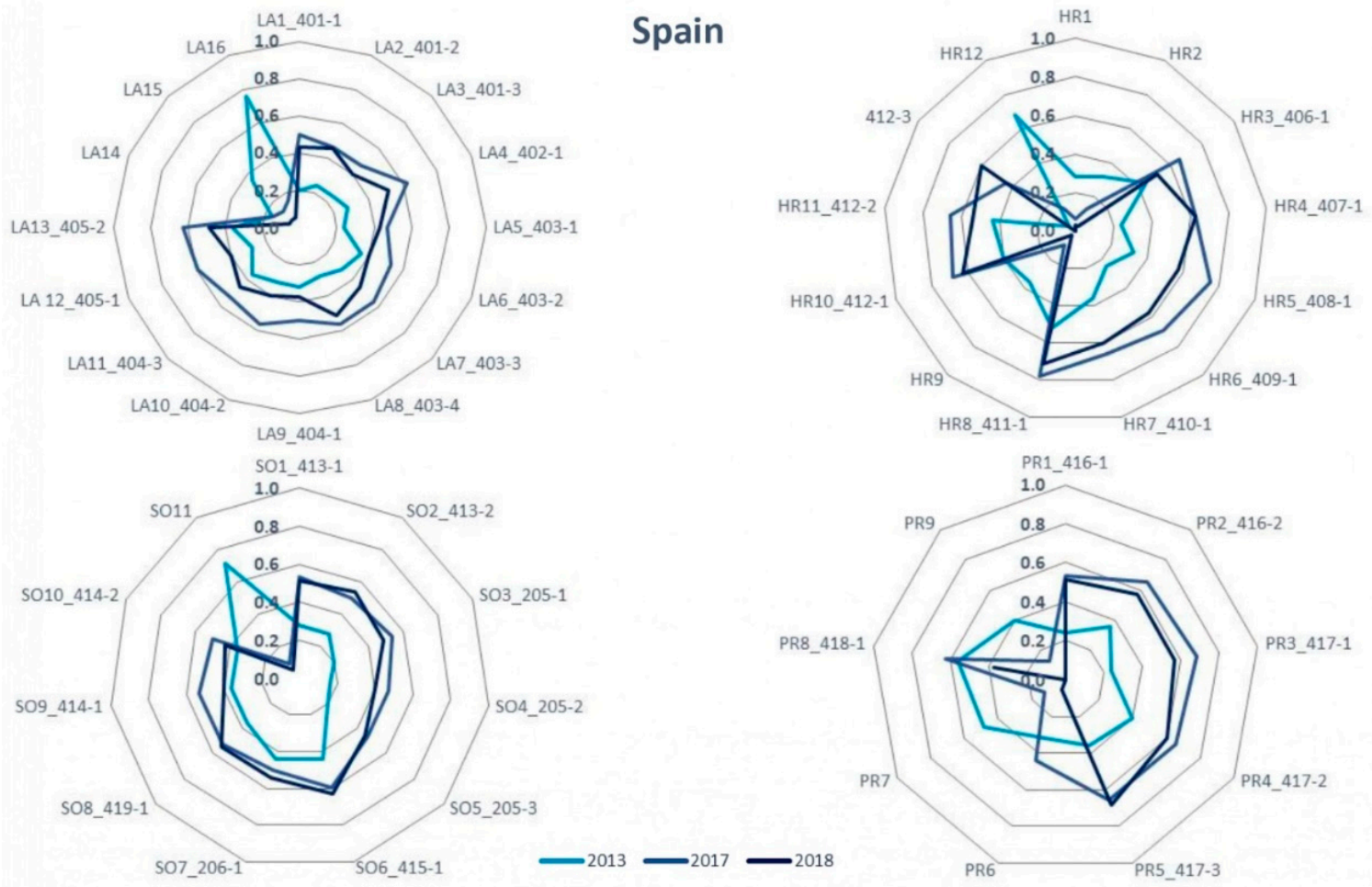

Figure 12. The use of the GRI social indicators in Spain.

Table 6. Assurance practices of NFI before and after the Directive 2014/95/EU.

\begin{tabular}{ccccccc}
\hline & \multicolumn{3}{c}{ Italy } & \multicolumn{3}{c}{ Spain } \\
\hline & $\mathbf{2 0 1 3}$ & $\mathbf{2 0 1 6}$ & $\mathbf{2 0 1 7}$ & $\mathbf{2 0 1 3}$ & $\mathbf{2 0 1 7}$ & $\mathbf{2 0 1 8}$ \\
\hline Assurance & $82 \%$ & $81 \%$ & $100 \%$ & $79 \%$ & $82 \%$ & $100 \%$ \\
\hline Provider & & & & & & \\
PWC & $29 \%$ & $23 \%$ & $42 \%$ & $18 \%$ & $39 \%$ & $32 \%$ \\
KPMG & $7 \%$ & $18 \%$ & $16 \%$ & $23 \%$ & $25 \%$ & $24 \%$ \\
E\&Y & $29 \%$ & $32 \%$ & $23 \%$ & $18 \%$ & $18 \%$ & $21 \%$ \\
Deloitte & $21 \%$ & $27 \%$ & $19 \%$ & $27 \%$ & $18 \%$ & $21 \%$ \\
Others & $14 \%$ & $0 \%$ & $0 \%$ & $14 \%$ & $0 \%$ & $3 \%$ \\
\hline Standard & & & & & & \\
ISAE3000 & $79 \%$ & $95 \%$ & $100 \%$ & $45 \%$ & $68 \%$ & $74 \%$ \\
AA1000AS & $7 \%$ & $0 \%$ & $0 \%$ & $0 \%$ & $0 \%$ & $0 \%$ \\
Others & $7 \%$ & $5 \%$ & $0 \%$ & $41 \%$ & $32 \%$ & $26 \%$ \\
Not specified & $0 \%$ & $0 \%$ & $0 \%$ & $9 \%$ & $0 \%$ & $0 \%$ \\
Level & $7 \%$ & $0 \%$ & $0 \%$ & $5 \%$ & $0 \%$ & $0 \%$ \\
\hline Limited/Moderate & & & & & & \\
Reasonable/High & $76 \%$ & $100 \%$ & $100 \%$ & $77 \%$ & $89 \%$ & $97 \%$ \\
Mixed levels & $7 \%$ & $0 \%$ & $0 \%$ & $0 \%$ & $0 \%$ & $0 \%$ \\
Not specified & $0 \%$ & $0 \%$ & $0 \%$ & $9 \%$ & $11 \%$ & $3 \%$ \\
\hline and AA1000AS & $7 \%$ & $0 \%$ & $0 \%$ & $14 \%$ & $0 \%$ & $0 \%$ \\
\hline
\end{tabular}

Different studies have shown that ISAE 3000 and AA1000AS are the standards most commonly used to conduct assurance and are frequently adopted in combination (Simnett et al. 2009; Perego and Kolk 2012; Cooper and Owen 2014). The use of the ISAE 3000 has gradually increased from $79 \%$ to $100 \%$ in Italy and from $45 \%$ to $74 \%$ in Spain, while the combined use of the ISAE 3000 and the AA1000AS has decreased over time. Regarding the levels of assurance provided, this study found that the limited/moderate assurance level increased in both countries, reaching the totality of NFI reports in Italy. The use of different assurance levels (i.e., limited and reasonable) for different matters of the 
same NFI report was found only in Spanish assurance statements, although their adoption was very low compared to the use of the limited/moderate assurance.

\section{Discussion and Conclusions}

This study aimed to investigate the effects produced by the new NFI regulation focusing on two European countries, Italy and Spain. These countries are characterised by similar legal systems (positive law), the same territorial context (Mediterranean countries), and similar civil law systems but with different regulatory backgrounds relating to nonfinancial disclosure.

We used content analysis to verify the level of NFI disclosed by Italian and Spanish listed companies before and after the publication of the Directive and its implementation in the two national legislations. Changes in disclosure levels were examined by constructing a disclosure index based on the quantity of GRI indicators disclosed by the sampled companies in their nonfinancial reports. The index measured the economic, environmental, and social disclosure performance achieved by companies over three years $(2013,2016$, and 2017 for Italy; 2013, 2017, and 2018 for Spain), making it possible to identify differences between the two countries in the disclosure of NFI during the transition stage marked by the introduction of the new law.

Our analysis shows that before the Directive's publication, Italian companies were less active in publishing sustainability reports than Spanish companies, among which $95 \%$ had already disclosed NFI. This result can be explained by the prior legislation on sustainability reporting introduced by the Spanish government and by the strong commitment and leading position taken by Spain in this area (de la Cuesta and Valor 2013; Reverte 2015; Sierra-Garcia et al. 2018). The maturity of the NFI reporting process in Spain might justify the belated transposition of EU requirements into national law, which probably indicates a lack of urgency in this regard (Sierra-Garcia et al. 2018). Consequently, the Directive's introduction represented an opportunity to promote NFI disclosure practices more in Italy than in Spain. According to Venturelli et al. (2019), the Directive would have produced greater benefits in countries that were less proactive in the nonfinancial reporting field. Despite the widest experience observed in Spain, in 2013, the quantity of NFI voluntarily disclosed by Italian companies in their reports was significantly higher than that disclosed by Spanish companies. On the one hand, this finding could stem from the greater flexibility and the interest in satisfying stakeholders' information needs that typically characterise the voluntary approach (Meek et al. 1995; Boesso and Kumar 2007). On the other hand, as Andrades et al. (2019) suggested, a higher quantity of information does not necessarily imply greater transparency.

The longitudinal analysis reveals different trends in the disclosure index of Italian and Spanish companies, suggesting different responses to the new regulation. In Italy, we detected a progressive reduction in disclosure levels that involved the three indicator categories, especially the economic category. The same trend was found in previous studies that analysed the dynamics in the use of GRI indicators before and after the entry into force of the Italian Decree (Loprevite et al. 2020; Raucci and Tarquinio 2020; Tarquinio et al. 2020). This reduction might be regarded as the need to report only information considered material according to the Decree, leading to the identification of a factor of razionalisation in the new regulation that supports more effective communication with stakeholders (Raucci and Tarquinio 2020; Tarquinio et al. 2020). This interpretation is consistent with previous research, according to which a lower quantity of information is not associated with a decrease in quality (Crawford and Williams 2010; Loprevite et al. 2020). Furthermore, considering the provision of mandatory assurance of NFI, the reduced amount of NFI might suggest a prudent approach to disclosure that induces companies to review the content of their NFI reports (Raucci and Tarquinio 2020; Tarquinio et al. 2020). A similar behaviour could also be associated with a "tick-box" mentality under which companies exhibit an apparently responsible behaviour, simply aimed at compliance (Caputo et al. 2020; Tarquinio et al. 2020). 
In contrast to the case for Italian companies, Spanish companies expanded the quantity of NFI disclosed following the Directive's implementation. Specifically, in 2017, we observed a significant increase in the average value of the disclosure index, followed by a slight decrease in 2018. This last reduction was probably due to Law $11 / 2018$, which enforced Royal Decree-Law 18/2017, introducing relevant changes in the implementation of the Directive. In particular, the inclusion of more specific guidance on the topics to be reported, as well as the mandatory assurance of NFI, could explain a more cautious approach to reporting and, therefore, the reduced level of disclosure. This trend could also result from the lack of specification of noncompliance penalties in Law 11/2018, which might induce companies to omit certain information.

Nevertheless, the higher disclosure levels reached from the period preceding the publication of the Directive suggest an opposite impact on Spanish reporting compared with that produced in Italy. The increase in disclosure levels can be interpreted in different ways. On the one hand, as suggested in the literature, it could be the expression of the positive attitude towards compliance that generally drives companies operating in countries with prior regulation (Crawford and Williams 2010; Dumitru et al. 2017; Venturelli et al. 2019). On the other hand, given the ineffectiveness of the previous regulation (LuqueVílchez and Larrinaga 2016; Sierra-Garcia et al. 2018), there was still an information gap in the reports of Spanish companies, making it necessary to broaden their content to comply properly with the new law. Moreover, greater disclosure levels could be associated with the IBEX-35 companies' aim to be included in sustainability indexes and thus enhance their reputation (de la Cuesta and Valor 2013). Indeed, the NFI Directive has represented a great opportunity for sustainable competitiveness (Matuszak and Różańska 2017), requiring companies to make greater efforts to distinguish themselves in the rankings.

The results on the evolution of NFI disclosure levels show that the EU Directive has had an impact on Italian and Spanish NFI reporting practices. Using the institutional theory lens, we can assume that NFI disclosure is affected not only by company-specific factors (Dyduch and Krasodomska 2017; Tarquinio et al. 2018; Mion and Loza Adaui 2019; Tiron-Tudor et al. 2019) but also by coercive pressures from the regulatory environment. Previous research has suggested that an increase in the amount of nonfinancial disclosure following the introduction of a mandatory regime indicates a movement towards normativity (Chauvey et al. 2015), considered by Bebbington et al. (2012) to be the degree to which rules and practices become accepted and standardised in a country. Based on our results, mandatory NFI reporting has reached higher levels of normativity in Spain than in Italy. Indeed, the production of normativity not only depends on formal legislation but also stems from structural elements, such as the congruence of legislation with previous practices and the existence of prior norms (Bebbington et al. 2012; Luque-Vílchez and Larrinaga 2016). In Spain, the new requirements set by the EU Directive fit with the existing reporting landscape, where governmental initiatives had already been taken to support the development of responsible practices among companies. The Spanish strategy on companies' corporate social responsibility practices 2014/2020 paved the way for the consolidation of an authentic sustainability culture in Spain, complementing previous laws (e.g., the SEL) and orienting other similar initiatives around Europe, even in the area of sustainability reporting (Reverte 2015). The provision of informal rules on making and applying the law represents another important source of normativity (Bebbington et al. 2012). Law 11/2018 references the use of the GRI Standards as a reporting framework, suiting the established reliance of Spanish companies on GRI reporting guidelines and laying further grounds for becoming a norm (Luque-Vílchez and Larrinaga 2016). These structural elements contribute to creating the normative climate necessary to enforce the law and introduce effective institutional changes (Luque-Vílchez and Larrinaga 2016). In contrast, certain conditions render the Italian scenario less supportive of the path towards NFI reporting normativity. For example, the Italian transposition law has gone beyond EU provisions, including more prescriptive requirements in relation to the ESG factors to be reported. This additional demand not only fails to reflect the limited experience of Italian companies in the field but is also not 
supported by the provision of specific guidance on which performance indicators should be used to measure and disclose such ESG factors (Jeffwitz and Gregor 2017).

The sectorial analysis over the whole period analysed underlined relevant discrepancies in the reporting of NFI among companies in different sectors, in accordance with other studies that showed how the company sector is an important determinant of disclosure performance (Sierra-Garcia et al. 2018; Caputo et al. 2020; Raucci and Tarquinio 2020). Consumer goods was the best performing sector in Italy, while the consumer services sector reached the highest performance in Spain. The lowest values of the disclosure index were observed in the health care sector in Italy and the consumer goods sector in Spain.

Furthermore, our results revealed a decrease in the wide gap previously observed between the quantity of information reported in the two analysed countries. In 2013, the disclosure index assumed average values equal to 0.75 in Italy and 0.34 in Spain. After the Directive's implementation, Italian companies achieved an average index of 0.42 , and Spanish companies achieved an average index of 0.52. This supports the hypothesis that regulation can support an alignment in NFI levels, leading to the harmonisation of information disclosed by European companies (La Torre et al. 2018; Mion and Loza Adaui 2019; Caputo et al. 2020). In this way, mandated disclosure can be seen as "a kind of magical minimalism that delivers significant rewards" (Hess 2019, p. 7).

Our paper has theoretical and practical implications. It contributes to the literature on the effects of mandatory NFI, increases the understanding of companies' reporting practices before and after the Directive, and provides insights into the main strengths and weaknesses of mandatory nonfinancial disclosure. Moreover, the cross-country analysis enables us to evaluate companies' responses to the new regulation considering different previous reporting experiences.

Our study may also have implications for policymakers, helping them assess the effectiveness of the European intervention in promoting nonfinancial reporting during the first stage of the implementation of the new law. Our findings can support the definition of strategies useful for improving the harmonisation of NFI disclosure practices and for establishing global sustainability reporting standards, as foreseen in the agenda of the "Group of Five" standard-setting organizations (CDP, the Climate Disclosure Standards Board, GRI, the International Integrated Reporting Council, and the Sustainability Accounting Standards Board). Furthermore, under this new scenario for NFI reporting, it might be of interest for standard setters to have high quality and comparable data on sustainability performance. Therefore, the development and/or refinement of performance indicators on sustainability issues will become important.

Our study also has some limitations that pave the way for future research. First, the comparative analysis is limited to the Italian and Spanish cases; therefore, the impact of the Directive on the harmonisation of NFI could be investigated more deeply by considering other European countries. Future studies may assess companies' disclosure index in the years following the first adoption of the Directive to better appreciate the evolutionary path of compulsory NFI disclosure in Europe. It would also be interesting to examine changes produced by regulatory requirements in the quantity and quality of information and test the relationship between NFI disclosure levels, corporate performance, and countryspecific factors.

Author Contributions: Conceptualization, writing and review, S.C.P. and L.T.; methodology, S.C.P.; data curation, S.C.P.; investigation. S.C.P.; formal analysis, S.C.P. All authors have read and agreed to the published version of the manuscript.

Funding: This research received no external funding.

Conflicts of Interest: The authors declare no conflict of interest. 


\section{References}

Allini, Alessandra, and Francesca Manes-Rossi. 2007. The Evolution of Nonfinancial Disclosure in a European Perspective. The Fondazione Eni Enrico Mattei Series Index, Milano. Available online: http://www.feemdeveloper.net/attach/CSR2007-014.pdf (accessed on 23 June 2020).

Andrades, Javier, Domingo Martinez-Martinez, Manuel Larran, and Jesus Herrera. 2019. Online information disclosure in Spanish municipal-owned enterprises. Online Information Review 43: 922-44. [CrossRef]

Artene, Alin, Ovidiu-Constantin Bunget, Alin-Constantin Dumitrescu, Aura-Emanuela Domil, and Oana Bogdan. 2020. Non-Financial Information Disclosures and Environmental Protection-Evidence from Romania and Greece. Forests 11: 814. [CrossRef]

Aureli, Selena, Elisabetta Magnaghi, and Federica Salvatori. 2019. The role of existing regulation and discretion in harmonising nonfinancial disclosure. Accounting in Europe 16: 290-312. [CrossRef]

Aureli, Selena, Federica Salvatori, and Elisabetta Magnaghi. 2020. A Country-Comparative Analysis of the Transposition of the EU Non-Financial Directive: An Institutional Approach. Accounting, Economics, and Law: A Convivium 10: 1-30. [CrossRef]

Bebbington, Jan, Elizabeth A. Kirk, and Carlos Larrinaga. 2012. The production of normativity: A comparison of reporting regimes in Spain and the UK. Accounting, Organizations and Society 37: 78-94. [CrossRef]

Boesso, Giacomo, and Kamalesh Kumar. 2007. Drivers of Corporate voluntary disclosure: A framework and empirical evidence from Italy and the United States. Accounting, Auditing and Accountability Journal 20: 269-96. [CrossRef]

Boiral, Olivier. 2013. Sustainability reports as simulacra? A counter-account of A and A+ GRI reports. Accounting, Auditing $\mathcal{E}$ Accountability Journal 26: 1036-71. [CrossRef]

Caputo, Fabio, Rossella Leopizzi, Simone Pizzi, and Virginia Milone. 2020. The Nonfinancial Reporting Harmonization in Europe: Evolutionary Pathways Related to the Transposition of the Directive 95/2014/EU within the Italian Context. Sustainability 12: 92. [CrossRef]

Caputo, Fabio, Simone Pizzi, Lorenzo Ligorio, and Rossella Leopizzi. 2021. Enhancing environmental information transparency through corporate social responsibility reporting regulation. Business Strategy and Environment, 1-15. [CrossRef]

Carini, Cristian, Laura Rocca, Monica Veneziani, and Claudio Teodori. 2018. Ex-ante impact assessment of sustainability informationthe directive 2014/95. Sustainability 10: 560. [CrossRef]

Carungu, Jonida, Roberto Di Pietra, and Matteo Molinari. 2020. Mandatory vs voluntary exercise on nonfinancial reporting: Does a normative/coercive isomorphism facilitate an increase in quality? Meditari Accountancy Research 29. [CrossRef]

Chauvey, Jean-Noël, Sophie Giordano-Spring, Charles H. Cho, and Dennis M. Patten. 2015. The normativity and legitimacy of CSR disclosure: Evidence from France. Journal of Business Ethics 130: 789-803. [CrossRef]

Cooke, Terence E. 1989. Voluntary corporate disclosure by Swedish companies. Journal of International Financial Management E Accounting 1: 171-95.

Cooper, Stuart, and David Owen. 2014. Independent assurance of sustainability reports. In Sustainability Accounting and Accountability. Edited by Jan Bebbington, Jeffrey Unerman and Brendan ODwyer '. London and New York: Routledge, pp. 72-85.

Crawford, Elise Perrault, and Cynthia Clark Williams. 2010. Should corporate social reporting be voluntary or mandatory? Evidence from the banking sector in France and the United States. Corporate Governance: International Journal of Business in Society 10: 512-26. [CrossRef]

CSR Europe, and Global Reporting Initiative (GRI). 2017. Member State Implementation of Directive 2014/95/EU A Comprehensive Overview of How Member States are Implementing the EU Directive on Nonfinancial and Diversity Information. Available online: https: / www.accountancyeurope.eu/wp-content/uploads/1711-NFRpublication-GRI-CSR-Europe.pdf (accessed on 26 August 2021).

Curtó-Pagès, Ferran, Enrique Ortega-Rivera, Marc Castellón-Durán, and Eva Jané-Llopis. 2021. Coming in from the cold: A longitudinal analysis of SDG reporting practices by Spanish listed companies since the approval of the 2030 agenda. Sustainability 13 : 1178 . [CrossRef]

Dagilienè, Lina, and Rūta Nedzinskienè. 2018. An institutional theory perspective on nonfinancial reporting. Journal of Financial Reporting and Accounting 16: 490-521. [CrossRef]

de la Cuesta, Marta, and Carmen Valor. 2013. Evaluation of the environmental, social and governance information disclosed by Spanish listed companies. Social Responsibility Journal 9: 220-40. [CrossRef]

DiMaggio, Paul J., and Walter W. Powell. 1983. The iron cage revisited: Institutional isomorphism and collective rationality in organizational fields. American Sociological Review 48: 147-60. [CrossRef]

Diouf, Dominique, and Olivier Boiral. 2017. The quality of sustainability reports and impression management: A stakeholder perspective. Accounting, Auditing \& Accountability Journal 30: 643-67. [CrossRef]

Doni, Federica, Silvio Bianchi Martini, Antonio Corvino, and Michela Mazzoni. 2019. Voluntary versus mandatory nonfinancial disclosure: EU Directive 95/2014 and sustainability reporting practices based on empirical evidence from Italy. Meditari Accountancy Research 28: 781-802. [CrossRef]

Dumitru, Mădălina, Justyna Dyduch, Raluca-Gina Gușe, and Joanna Krasodomska. 2017. Corporate reporting practices in Poland and Romania-an ex-ante study to the new nonfinancial reporting European Directive. Accounting in Europe 14: 279-304. [CrossRef]

Dyduch, Justyna, and Joanna Krasodomska. 2017. Determinants of corporate social responsibility disclosure: An empirical study of Polish listed companies. Sustainability 9: 1934. [CrossRef] 
EU Commission. 2014. Directive 2014/95/EU of the European Parliament and the Council of 22 October 2014 Amending Directive 2013/34/EU as Regards Disclosure of Non-Financial and Diversity Information by Certain Large Undertakings and Groups. Brussels: EU Commission.

Fonseca, Alberto, Amanda Macdonald, Emily Dandy, and Paul Valenti. 2011. The state of sustainability reporting at Canadian universities. International Journal of Sustainability in Higher Education 12: 22-40. [CrossRef]

Gallego, Isabel. 2006. The use of economic, social and environmental indicators as a measure of sustainable development in Spain. Corporate Social Responsibility and Environmental Management 13: 78-97. [CrossRef]

García Sánchez, Isabel-María, Pilar Martín Zamora, Maricela Ramírez, María Del Carmen Granada Abarzuza, and Lázaro Rodríguez Ariza. 2019. La Divulgación De Información No Financiera En España. XX Congreso Internacional AECA Málaga, del 25 al 27 de septiembre de 2019 Construyendo Empresas Viables para un Futuro Sostenible. Available online: https:/ /xxcongreso.aeca.es / wp-content/uploads/2019/09/29a.pdf (accessed on 26 August 2021).

García-Sánchez, Isabel-María, and Cristina-Andrea Araújo-Bernardo. 2020. What colour is the corporate social responsibility report? Structural visual rhetoric, impression management strategies, and stakeholder engagement. Corporate Social Responsibility and Environmental Management 27: 1117-42. [CrossRef]

García-Sánchez, Isabel-María, Beatriz Cuadrado-Ballesteros, and Jose-Valeriano Frias-Aceituno. 2016. Impact of the institutional macro context on the voluntary disclosure of CSR information. Long Range Planning 49: 15-35. [CrossRef]

Garcia-Torea, Nicolas, Carlos Larrinaga, and Mercedes Luque-Vílchez. 2020. Academic engagement in policy-making and social and environmental reporting. Sustainability Accounting, Management and Policy Journal 11: 281-90. [CrossRef]

Global Reporting Initiative (GRI). 2012. GRI G3 and G3.1 Update-Comparison Sheet. Available online: https://www.globalreporting. org/resourcelybrary/G3.1-Comparison-Sheet.pdf (accessed on 10 December 2019).

Global Reporting Initiative (GRI). 2013. Overview of Changes in Standard Disclosures from G3.1 to G4 Guidelines. Available online: https:/ / www.globalreporting.org/resourcelybrary/GRI-G4-Overview-Tables-g3.1-vs-G4.pdf (accessed on 10 December 2019)

Global Reporting Initiative (GRI). 2016. GRI Sustainability Reporting Standards. Available online: https://www.globalreporting.org/ standards/ (accessed on 20 August 2020).

Global Reporting Initiative (GRI). 2017a. Mapping G4 to the GRI Standards. Available online: https:/ /www.globalreporting.org/ standards/media/1098/mapping-g4-to-the-gri-standards-disclosures-full-overview.pdf (accessed on 10 December 2019).

Global Reporting Initiative (GRI). 2017b. Linking the GRI Standards and the European Directive on Non-Financial and Diversity Disclosure. Available online: https:/ / asvis.it/public/asvis/files/linkingGRI.pdf (accessed on 10 December 2019).

Guthrie, James, and Federica Farneti. 2008. GRI sustainability reporting by Australian public sector organizations. Public Money and Management 28: 361-66. [CrossRef]

Hąbek, Patrycja, and Radosław Wolniak. 2016. Assessing the quality of corporate social responsibility reports: The case of reporting practices in selected European Union member states. Quality $\mathcal{E}$ Quantity 50: 399-420. [CrossRef]

Hess, David. 2019. The Transparency Trap: Nonfinancial Disclosure and the Responsibility of Business to Respect Human Rights. American Business Law Journal 56: 5-53. [CrossRef]

Jeffwitz, Claire, and Filip Gregor. 2017. Comparing the Implementation of the EU Nonfinancial Reporting Directive. Available online: http:/ / www.purposeofcorporation.org/comparing-the-eu-non-financial-reporting-directive.pdf (accessed on 19 November 2020).

Kolk, Ans. 2010. Trajectories of sustainability reporting by MNCs. Journal of World Business 45: 367-74. [CrossRef]

Korca, Blerita, Ericka Costa, and Federica Farneti. 2021. From voluntary to mandatory nonfinancial disclosure following Directive 2014/95/EU: An Italian case study. Accounting in Europe 1-25. [CrossRef]

KPMG. 2008. International Survey of Corporate Responsibility Reporting 2008. Available online: https:/ /www.scirp.org/(S(i43dyn4 5teexjx455qlt3d2q))/reference/ReferencesPapers.aspx?ReferenceID=1869862 (accessed on 26 August 2021).

KPMG. 2011. KPMG International Survey of Corporate Responsibility Reporting 2011. Available online: https://www.eticanews.it/ wp-content/uploads/2011/12/CR_Report_2011_v10.pdf (accessed on 26 August 2021).

KPMG. 2020. The Time has Come, The KPMG Survey of Sustainability Reporting 2020, December. Available online: https://home. kpmg/xx/en/home/insights/2020/11/the-time-has-come-survey-of-sustainability-reporting.html (accessed on 26 August 2021).

La Torre, Matteo, Svetlana Sabelfeld, Marita Blomkvist, Lara Tarquinio, and John Dumay. 2018. Harmonising nonfinancial reporting regulation in Europe. Meditari Accountancy Research 26: 598-621. [CrossRef]

Leopizzi, Rossella, Antonio Iazzi, Andrea Venturelli, and Salvatore Principale. 2019. Nonfinancial risk disclosure: The 'state of the art' of Italian companies. Corporate Social Responsibility and Environmental Management 27: 358-68. [CrossRef]

Lombardi, Rosa, Antonietta Cosentino, Alessandro Sura, and Michele Galeotti. 2021. The impact of the EU Directive on nonfinancial information: Novel features of the Italian case. Meditari Accountancy Research. [CrossRef]

Loprevite, Salvatore, Domenico Raucci, and Daniela Rupo. 2020. KPIs Reporting and Financial Performance in the Transition to Mandatory Disclosure: The Case of Italy. Sustainability 12: 5195. [CrossRef]

Luque-Vílchez, Mercedes, and Carlos Larrinaga. 2016. Reporting models do not translate well: Failing to regulate CSR reporting in Spain. Social and Environmental Accountability Journal 36: 56-75. [CrossRef]

Manes-Rossi, Francesca, Adriana Tiron-Tudor, Giuseppe Nicolò, and Gianluca Zanellato. 2018. Ensuring more sustainable reporting in Europe using nonfinancial disclosure-De facto and de jure evidence. Sustainability 10: 1162. [CrossRef]

Martínez-Ferrero, Jennifer, and Isabel-María García-Sánchez. 2017. Coercive, normative and mimetic isomorphism as determinants of the voluntary assurance of sustainability reports. International Business Review 26: 102-18. [CrossRef] 
Martínez-Ferrero, Jennifer, and Isabel-María García-Sánchez. 2018. The level of sustainability assurance: The effects of brand reputation and industry specialisation of assurance providers. Journal of Business Ethics 150: 971-90. [CrossRef]

Matuszak, Łukasz, and Ewa Różańska. 2017. CSR disclosure in Polish-listed companies in the light of Directive 2014/95/EU requirements: Empirical evidence. Sustainability 9: 2304. [CrossRef]

Mazzotta, Romilda, Giovanni Bronzetti, and Stefania Veltri. 2020. Are mandatory nonfinancial disclosures credible? Evidence from Italian listed companies. Corporate Social Responsibility and Environmental Management 27: 1900-13. [CrossRef]

Meek, Gary K., Clare B. Roberts, and Sidney J. 1995. Factors influencing voluntary annual report disclosures by US, UK and continental European multinational corporations. Journal of International Business Studies 26: 555-72. [CrossRef]

Meyer, John W., and Brian Rowan. 1977. Institutionalized organizations: Formal structure as myth and ceremony. American Journal of Sociology 83: 340-63. [CrossRef]

Mio, Chiara, and Andrea Venturelli. 2013. Nonfinancial information about sustainable development and environmental policy in the annual reports of listed companies: Evidence from Italy and the UK. Corporate Social Responsibility and Environmental Management 20: 340-58. [CrossRef]

Mion, Giorgio, and Cristian R. Loza Adaui. 2019. Mandatory nonfinancial disclosure and its consequences on the sustainability reporting quality of Italian and German companies. Sustainability 11: 4612. [CrossRef]

Montesinos, Vicente, and Isabel Brusca. 2019. Nonfinancial Reporting in the Public Sector: Alternatives, Trends and Opportunities. Revista de Contabilidad Spanish Accounting Review 22: 122-28. [CrossRef]

Moseñe, José A., Roger L. Burritt, M. Victoria Sanagustín, José M. Moneva, and Joanne Tingey-Holyoak. 2013. Environmental reporting in the Spanish wind energy sector: An institutional view. Journal of Cleaner Production 40: 199-211. [CrossRef]

Nicolò, Giuseppe, Gianluca Zampone, Giuseppe Sannino, and Serena De Iorio. 2021. Sustainable corporate governance and nonfinancial disclosure in Europe: Does the gender diversity matter? Journal of Applied Accounting Research. [CrossRef]

Nicolò, Giuseppe, Gianluca Zanellato, and Adriana Tiron-Tudor. 2020. Integrated Reporting and European State-Owned Enterprises: A Disclosure Analysis Pre and Post 2014/95/EU. Sustainability 12: 1908. [CrossRef]

Perego, Paolo, and Ans Kolk. 2012. Multinationals' accountability on sustainability: The evolution of third-party assurance of sustainability reports. Journal of Business Ethics 110: 173-90. [CrossRef]

Pizzi, Simone, Andrea Venturelli, and Fabio Caputo. 2020. The "comply-or-explain" principle in directive 95/2014/EU. A rhetorical analysis of Italian PIEs. Sustainability Accounting, Management and Policy Journal 12: 30-50. [CrossRef]

Pizzi, Simone, Francesco Rosati, and Andrea Venturelli. 2021. The determinants of business contribution to the 2030 Agenda: Introducing the SDG Reporting Score. Business Strategy and the Environment 30: 404-21. [CrossRef]

Raffournier, Bernard. 1995. The determinants of voluntary financial disclosure by Swiss listed companies. European Accounting Review 4: 261-80. [CrossRef]

Rahman, Sohanur, Tehmina Khan, and Pavithra Siriwardhane. 2019. Sustainable development carbon pricing initiative and voluntary environmental disclosures quality. Business Strategy and the Environment 28: 1072-82. [CrossRef]

Raucci, Domenico, and Lara Tarquinio. 2020. Sustainability Performance Indicators and Nonfinancial Information Reporting. Evidence from the Italian Case. Administrative Sciences 10: 13. [CrossRef]

Raucci, Domenico, Lara Tarquinio, Daniela Rupo, and Salvatore Loprevite. 2020. Nonfinancial performance indicators: The power of measures to operationalize the law. In Sustainability and Law. Edited by Volker Mauerhofer, Daniela Rupo and Lara Tarquinio. Cham: Springer, pp. 275-91. [CrossRef]

Reverte, Carmelo. 2015. The new Spanish corporate social responsibility strategy 2014-2020: A crucial step forward with new challenges ahead. Journal of Cleaner Production 91: 327-36. [CrossRef]

Roca, Laurence Clément, and Cory Searcy. 2012. An analysis of indicators disclosed in corporate sustainability reports. Journal of Cleaner Production 20: 103-18. [CrossRef]

Romero, Silvia, Silvia Ruiz, and Belén Fernàndez-Feijòo. 2010. Assurance Statement for Sustainability Reports: The Case of Spain. Proceedings of the Northeast Business \& Economics Association 1: 105-12.

Shabana, Kareem M., Ann K. Buchholtz, and Archie B. Carroll. 2017. The institutionalization of corporate social responsibility reporting. Business \& Society 56: 1107-35. [CrossRef]

Sierra-Garcia, Laura, Maria Antonia Garcia-Benau, and Helena Maria Bollas-Araya. 2018. Empirical analysis of nonfinancial reporting by Spanish companies. Administrative Sciences 8: 29. [CrossRef]

Simnett, Roger, Ann Vanstraelen, and Wai Fong Chua. 2009. Assurance on sustainability reports: An international comparison. Accounting Review 84: 937-67. [CrossRef]

Skouloudis, Antonis, Konstantinos Evangelinos, and Fotis Kourmousis. 2009. Development of an evaluation methodology for triple bottom line reports using international standards on reporting. Environmental Management 44: 298-311. [CrossRef] [PubMed]

Suchman, Mark C. 1995. Managing legitimacy: Strategic and institutional approaches. Academy of Management Review 20: 571-610. [CrossRef]

Tarquinio, Lara, Domenico Raucci, and Roberto Benedetti. 2018. An investigation of global reporting initiative performance indicators in corporate sustainability reports: Greek, Italian and Spanish evidence. Sustainability 10: 897. [CrossRef]

Tarquinio, Lara, Domenico Raucci, Ida Verna, and Roberto Benedetti. 2015. GRI performance indicators and corporate variables. Evidence from Italian listed companies' corporate social responsibility reports. Progress in Industrial Ecology an International Journal 9: 234-55. [CrossRef] 
Tarquinio, Lara, Stefanía C. Posadas, and Deborah Pedicone. 2020. Scoring Nonfinancial Information Reporting in Italian Listed Companies: A Comparison of before and after the Legislative Decree 254/2016. Sustainability 12: 4158. [CrossRef]

Tiron-Tudor, Adriana, Cristina Silvia Nistor, Cristina Alexandrina Ştefănescu, and Gianluca Zanellato. 2019. Encompassing Nonfinancial Reporting in A Coercive Framework for Enhancing Social Responsibility: Romanian Listed Companies'case. Amfiteatru Economic 21: 590-606. [CrossRef]

Veltri, Stefania, Francesco De Luca, and Ho-Tan-Phat Phan. 2020. Do investors value companies' mandatory nonfinancial risk disclosure? An empirical analysis of the Italian context after the EU Directive. Business Strategy and the Environment 29: 2226-37. [CrossRef]

Venturelli, Andrea, Fabio Caputo, Rossella Leopizzi, and Simone Pizzi. 2019. The state of art of corporate social disclosure before the introduction of nonfinancial reporting directive: A cross country analysis. Social Responsibility Journal 15: 409-23. [CrossRef]

Venturelli, Andrea, Fabio Caputo, Simona Cosma, Rossella Leopizzi, and Simone Pizzi. 2017. Directive 2014/95/EU: Are Italian companies already compliant? Sustainability 9: 1385. [CrossRef] 